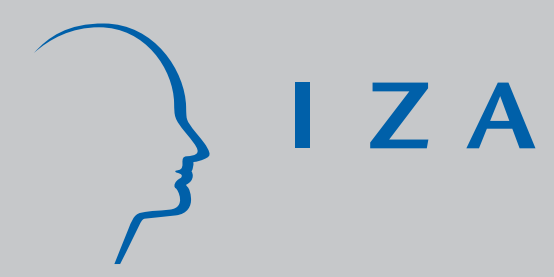

\begin{abstract}
IZA DP No. 141
The Effects of Public Sector Sponsored Training on Individual Employment Performance in East Germany
\end{abstract}

Reinhard Hujer

Marc Wellner

April 2000 


\title{
The Effects of Public Sector Sponsored Training on Individual Employment Performance in East Germany
}

\author{
Reinhard Hujer \\ J.W. Goethe-University, Frankfurt/Main and IZA, Bonn \\ Marc Wellner \\ J.W. Goethe-University, Frankfurt/Main
}

Discussion Paper No. 141

April 2000

\author{
IZA \\ P.O. Box 7240 \\ D-53072 Bonn \\ Germany \\ Tel.: +49-228-3894-0 \\ Fax: +49-228-3894-210 \\ Email: iza@iza.org
}

This Discussion Paper is issued within the framework of IZA's research area Project Evaluation. Any opinions expressed here are those of the author(s) and not those of the institute. Research disseminated by IZA may include views on policy, but the institute itself takes no institutional policy positions.

The Institute for the Study of Labor (IZA) in Bonn is a local and virtual international research center and a place of communication between science, politics and business. IZA is an independent, nonprofit limited liability company (Gesellschaft mit beschränkter Haftung) supported by the Deutsche Post AG. The center is associated with the University of Bonn and offers a stimulating research environment through its research networks, research support, and visitors and doctoral programs. IZA engages in (i) original and internationally competitive research in all fields of labor economics, (ii) development of policy concepts, and (iii) dissemination of research results and concepts to the interested public. The current research program deals with (1) mobility and flexibility of labor markets, (2) internationalization of labor markets and European integration, (3) the welfare state and labor markets, (4) labor markets in transition, (5) the future of work, (6) project evaluation and (7) general labor economics.

IZA Discussion Papers often represent preliminary work and are circulated to encourage discussion. Citation of such a paper should account for its provisional character. 
IZA Discussion Paper No. 141

April 2000

\section{ABSTRACT \\ The Effects of Public Sector Sponsored Training on Individual Employment Performance in East Germany*}

This study analyses the effects of public sector sponsored vocational training on individual unemployment and employment duration in East Germany. The data is taken from the German Socio-Economic Panel (GSOEP). The empirical analysis is limited to training measures that took place between July 1990 and June 1993. To resolve the intriguing sample selection problem, i.e. to find an adequate control group for the group of trainees, we employ matching methods. The training effect is be estimated by using a discrete time hazard rate model. In the empirical analysis no evidence can be found to show that participation in public vocational training significantly decreases unemployment duration or increases employment duration.

JEL Classification: C40, J20, J64

Keywords: Discrete hazard models, selection bias, matching methods

Reinhard Hujer

J.W. Goethe-University Frankfurt/Main

Mertonstraße 17

60054 Frankfurt/Main

Germany

Fax.: +49 79823673

Email: hujer@wiwi.uni-frankfurt.de

\footnotetext{
* Financial support from the Deutsche Forschungsgemeinschaft is gratefully acknowledged. The authors want to thank especially Hilmar Schneider for the permission to use his GAUSS library for the estimation of discrete hazard models, and Joachim Grammig and Kai-Oliver Maurer for helpful comments and criticism.
} 


\section{INTRODUCTION}

Since 1969 publicly sponsored vocational training in West Germany has been regulated by the Work Support Act (Arbeitsförderungsgesetz, AFG). From then onwards high and almost yearly increasing amounts of public resources have been invested into the support of vocational training by the Federal Labor Office (Bundesanstalt für Arbeit). After the reunification in 1990, due to the large effects of the transformation process on the labor market, public vocational training played an even more important role in the eastern part of Germany. For example, in 1992 the Federal Labor Office spent more than DM 7.6 billion (DM 11.3 billion) on the support of vocational training in the western (eastern) part of Germany despite a labor force in East Germany that was nearly $75 \%$ smaller than in West Germany.

Due to the $10^{\text {th }}$ reform of the Work Support Act expenditures for publicly sector sponsored vocational training were reduced quite dramatically from 1993 onwards. The increasing public budget deficits obviously brought up the question as to whether the benefits from participating in vocational training programs really outweighed the high costs of supporting it. Vocational training measures aim to influence different post-training labor market indicators (outcome variables). In this study we will focus on two indicators that describe post-training employment performance, on the one hand the duration of unemployment and on the other the duration of employment.

To evaluate the causal effects of vocational training on any kind of outcome one has to contrast the situation of the participants after training with the counterfactual situation in the absence of training. Because the latter situation is only hypothetical, i.e. not observable, it needs to be estimated, based on the outcome of other individuals who did not receive training, members of a so-called control group. In an experiment, the construction of an adequate control group is completed by means of randomization at the data collection level. In Germany only non-experimental data sets are available. Hence, reliable evaluations of training effects have to consider possible sample selection effects arising from non-random participation in training. Especially in the USA strong research efforts 
were made to develop different econometric and statistical adjustment procedures for the case of non-experimental data (e.g. Rosenbaum, Rubin (1983, 1985), Heckman, Robb (1985)). A comparison of their performance with results obtained in experimental evaluations brought mixed results. While particularly model based adjustment procedures hardly produced reliable estimates, varying widely and differing greatly from experimental estimates (LaLonde (1986)), matching methods performed better and were reasonably successful in replicating experimental results (see e.g. Dehejia, Wahba (1998a, 1998b), Heckman, Ichimura, Todd (1997)).

The recent past has seen a rapid increase in the number of training evaluations for Germany, the majority of them focusing on the eastern part of Germany. The reason for East Germany's relative popularity compared to West Germany is mainly based on the high quantitative relevance that training had during the transformation process after the reunification. As a result the data sets for East Germany show a higher proportion of participants than those for West Germany. The following overview will only focus on studies, respectively the results of studies that analyze the type of training which this study is interested in, namely publicly sponsored vocational training in East Germany.

Pannenberg (1995) uses a discrete hazard rate model to evaluate the effects of further training and retraining courses on unemployment duration in East Germany. The data is taken from the German Socio-Economic Panel (GSOEP) and covers the time span from 1990 to 1992. His results indicate the non-existence of significant training effects on reemployment chances. Payment of a maintenance allowance during further training and retraining even significantly decreases post-training reemployment chances. Using a linear panel data estimator with fixed effects Pannenberg (1995) also investigates the effects of training on earnings. His results point to a significant positive effect of further training and retraining courses on monthly earnings. In this case the payment of a maintenance allowance does not significantly affect these results. Fitzenberger, Prey $(1996,1997)$ explore the effects of training on employment probability and hourly wages in East Germany. The authors use the Labor Market Monitor (LMM) and cover the period 1990 to 1994 . In order to account for possible sample selection effects and panel attrition they utilize a dynamic simultaneous random 
effects model consisting of an employment, wage, qualification, attrition and initial condition equation. To identify the presence of any remaining selection effects before training the authors rely on the pre-program test proposed by Heckman, Hotz (1989). Since the applied test procedure indicates that their model does not completely correct for sample selection bias the authors take the remaining sample selection bias into consideration when interpreting their estimation results. In this respect they find that training in an external institution that is supported by a maintenance allowance has positive effects on employment probabilities. Regarding the employment effects of publicly supported training within a firm the authors find no significant influence for women and significant negative effects for men. Publicly supported training is found to have no effect on hourly wages regardless of whether it took place within the firm or outside it. Using the first three waves of the GSOEP for East Germany Staat (1997) separately examines the effects of further training and retraining courses that were supported by a maintenance allowance on unemployment and employment duration. Taking the estimated probability of participation in training as an instrument for the training participation dummy in the hazard rate model to account for possible sample selection effects, the author finds negative effects on employment duration and no significant effects on unemployment duration. On the basis of the LMM for the period 1993 to 1994 Hübler (1997) compares different evaluation estimators, such as random effects estimators with pre-program test, matched sampling methods or a combination of both, to investigate training effects on employment probabilities. The author finds that the results are very sensitive to the particular estimation approach taken. Based on a combination of matching and random effects estimator the author finds that while in the first period after training the effects on employment are negative, in later periods they become positive. If a separation is made between males and females, positive long run employment effects can only be detected for men. Based on data from the LMM for the period 1989 to 1994 Kraus, Puhani, Steiner (1999) analyze the effectiveness of publicly financed training and retraining on unemployment duration. They split the observation period into two subperiods, one until August 1992 and the other after. For the first period the public vocational training courses were found to have no positive effect at all. During the later period significant positive effects are detected on the transition into stable employment. For women both on- and 
off-the-job measures significantly improve reemployment chances while for men only the latter have a significant positive impact. Lechner (2000) uses GSOEP data from 1990 to 1996 to investigate the effects of further training and retraining measures that are supported by maintenance allowance. The author applies a matching approach to construct an adequate group of non-trainees who are similar to the trainees in all relevant pre-training characteristics. Based on the resulting matched sample the author then estimates the training effects for various post-training labor market outcomes such as unemployment, employment and earnings by calculating the difference in mean between the trainee and matched non-trainee groups. His results depict a negative picture of publicly sponsored training programs. In the short run, i.e. during the first few months after the end of training, the author finds that training increases unemployment. In the longer run no significant effects can be found. For post-training earnings no significant effects were found at all.

This study aims to contribute to the ongoing discussion of public sector sponsored vocational training in East Germany. We use the GSOEP, which is a very informative non-experimental German database to examine the effects of public sector financed vocational training on individual employment performance. Since the $10^{\text {th }}$ reform of the Work Support Act led to substantial changes concerning the training admission during 1993, the analysis is limited to the type of publicly subsidized training measures that originated before. This ensures that all trainees are subject to similar selection rules.

Due to the non-experimental nature of the data set a credible empirical training evaluation has to take into account the intriguing problem of sample selection. In this study the sample selection problem is resolved by means of matching methods proposed by Rosenbaum, Rubin (1985) and Rubin (1991) and adapted for example to the evaluation of training in East Germany by Lechner (2000). The matching approach bears a close resemblance to experimental evaluations since it tries to extend the ideas of the experimental framework to a non-experimental context. To obtain an adequate control group the matching procedure selects from the group of non-trainees those who are most similar to the trainees with respect to all relevant characteristics. The individual propensity to participate in training 
is used as the main matching variable. This is obtained by estimating a panel probit model. In addition, the matching procedure incorporates the monthly pre-training labor force status in order to account for transitory shocks just prior to training. In order to increase the efficiency of the estimated training effects an oversampling matching procedure that aims to find more than one similar non-trainee for each trainee is used instead of the standard one-to-one matching. Having constructed a matched sample that eliminates the necessity to control for selection into training. We consider as the relevant outcome variables the duration of unemployment and employment. This we need to use a hazard rate model (e.g. Ham, LaLonde $(1990,1996))$.

The study proceeds as follows: Section 2 presents some empirical developments in public sector sponsored vocational training and the labor markets in East Germany during the time under consideration. Section 3 describes the database and gives descriptive statistics for several characteristics of the chosen sample. Section 4 is devoted to the construction of an adequate control group. First we give a short theoretical outline of the evaluation problem and the approach we apply to deal with it. We then turn to the estimation of the propensity score for participation in training. Based on the estimated propensity score the application of the matching procedure follows to construct a matched sample. Section 5 deals with the evaluation of the impact of training on the labor market outcomes under consideration. A hazard rate model is utilized in order to estimate the training effects on unemployment and employment duration. Section 6 concludes this study.

\section{LABOR MARKETS AND PUBLICLY SPONSORED VOCATIONAL TRAINING in East Germany: Some Stylized facts}

With the opening of the borders in September 1989, economic and monetary union in May 1990 and finally the political reunification in October 1990 the East German economy underwent a fundamental transition process. The sudden exposure to a western-style economic environment as well as the loss of key trading partners in East Europe led to a sharp reduction in production which changed relative prices dramatically. After an initial decrease in gross domestic product (GDP) that lasted until the first quarter

of 1991, GDP grew from 1991 to 1994 on average by more than 8\% p.a. Due 
to political pressure to reduce the disparity in living standards between the eastern and western part of Germany and thus to avoid massive East-West migration, this was accompanied by an increase in the average growth rate of gross earnings per worker. Whereas in 1991 gross earnings per worker in East Germany were at a level of only $49 \%$ of the West German counterparts, in 1994 they were already at $74 \%$. The average annual increase in gross earnings per worker from 1991 to 1994 was nearly $15 \%$ p.a. Since many firms were not able to survive under the new economic circumstances and had to be shut down the demand for labor broke down substantially. The number of employed in East Germany fell by more than $30 \%$ from around 9.6 million in 1989 to around 6.2 million in 1993. As a result of this dramatic decline in labor demand (officially registered) unemployment occurred for the first time in East Germany. There was a tremendous increase in unemployment of 0.5 million people from around 140 thousand unemployed in June 1990 to around 640 thousand in December 1990 showing no seasonal pattern at all. This level of unemployment already amounted to an official unemployment rate of $6.3 \%$ in the $4^{\text {th }}$ quarter of 1990 nearly reaching West Germany's 1990 unemployment rate level of $7.2 \%$. Two further jumps occurred from June to July 1991 and from December 1991 to January 1992 leading to a peak of more than 1.3 million unemployed and an unemployment rate of $17.0 \%$.

The dramatic development of unemployment in East Germany brought about the political need to directly ease social hardship by keeping people off the dole. As a consequence the Federal Labor Office set up various measures of labor market policy. Four major types of subsidized measures were:

- early retirement regulations

- job-creation measures

- short-time work

- vocational training measures

For example in 1991 the sum of the four measures added up to on average more than 2 million individuals who were actually in "hidden" unemployment. In other words without active labor market policy the official rate of unemployment in 1991 would have been around 35\% instead of only $10.3 \%$. This clearly documents the high quantitative relevance of these 
instruments of active labor market policy. The importance of the different instruments fluctuated over time. While short-time work clearly dominated all other instruments immediately after the reunification, i.e. up to the end of 1991 the number of individuals affected by early retirement regulations increased continuously until 1993 when it reached its maximum importance. Job-creation and vocational training measures had their highest level in 1992.

In the first few years after the reunification the vocational training measures, which are the subject of this study, aimed to adjust the structure of the labor force in general to the new requirements of a western style economy. Since then the intention has become more in line with that pursued in the western part of Germany, i.e. to improve the reemployment prospects of the unemployed and to prevent the loss of their human capital during an unemployment episode. In principle public vocational training in Germany comprises of three types of training measures:

- The first type is further training (Fortbildung) in an occupation the participant is already trained in ( $\S 41-46$ AFG). One special focus of further training is to improve the labor market conditions for disadvantaged individuals, such as the long term unemployed, women, older people (Anpassungsfortbildung). Moreover further training is used to avoid supply shortages of labor with specific skills and to enhance advancement in an occupation (Aufstiegsfortbildung). Finally further training also includes short courses for the unemployed which aim to improve job search skills and to provide individuals with information about different types of work and training possibilities (Massnahmen zur Verbesserung der Vermittlungsaussichten) (§41a AFG).

- The second type is retraining (Umschulung). The aim is to offer participants the opportunity to train for a new occupation when their skills or qualification have become useless because of changing labor market conditions, e.g. technological changes. Thus retraining should help to improve occupational mobility. Retraining courses are regulated more strictly than further training courses and should be completed with a publicly approved examination ( $\$ 47$ AFG).

- The third type is training to familiarize the individual with a new occupation (Einarbeitung). The labor offices support employers for 
providing training for those employees who need a long time to familiarize themselves with a new job ( $\$ 49$ AFG).

In the case of job familiarization the Federal Labor Office's support is a wage subsidy passed on to employers. In contrast to job familiarization the first two types of training (further training and retraining) are typically off-the-job (classroom) courses. When certain conditions related to the employment history, the motivation and the personal situation of the applicant are met, the Federal Labor Office gives financial support to the participant (see $\S 36, \S 42, \S \S 44-47$ AFG). This support can cover the costs of the provision of the course as well as a maintenance allowance in the range of $60 \%$ to $75 \%$ of previous net earnings.

In order to gain an impression of the relevance of the different types of public vocational training measures the entries into these measures for East Germany each year are shown in figure 1.

Figure 1 about here

A striking feature is the strong increase in the absolute number of entries into public vocational training from 1990 to 1991 to a level of close to 900 thousand entries, which was $50 \%$ higher than in West Germany in the same year. These high numbers were maintained for a further year before the $10^{\text {th }}$ reform of the Work Support Act in 1992 resulted in sharp drop in entries from 1992 to 1993 . Turning our attention to the relative importance of the different types of measures it becomes obvious that further training and retraining account for the majority of all entries with a share of generally around 90\%. During the years 1991 and 1992 short courses according to $\S 41 \mathrm{a}$ AFG played a significant role to give many unemployed individuals a vocational orientation under the new economic system and labor market conditions. To obtain a rather homogeneous training effect our empirical analysis will focus on individuals who participated in further training and retraining and who received maintenance allowance during the training course. For example in the year 1992 this amounted to about 85\% of all entries into further training and retraining. In the following we will abbreviate this type of training by FRMA. In order to ensure that these individuals are subject to similar selection rules by the Federal Labor Office, we will only consider participants who began their training no later than 
early 1993, i.e. before the first major tightening rules which originated in early 1993.

\section{THE DATA BASE}

The sample used for the analysis is drawn from the German Socio-Economic Panel (GSOEP), a representative sample of the resident population. Starting in 1984, about 12000 individuals aged above 16 and belonging to nearly 6000 households have been interviewed on a yearly basis about subjects such as employment status, personal characteristics, education, various types of income etc. From 1990 onwards, just six months after the Berlin wall came down, the survey was expanded to East Germany, i.e. an additional sub-sample of 2000 East German households and 4500 individuals was added. Since our study is limited to East Germany, we will only use the latter sub-sample in our analysis. For a detailed description of the GSOEP see Hanefeld (1987), Projektgruppe Sozio-ökonomisches Panel (1998) or Wagner et al. (1993).

To generate the outcome variables of interest which describe the post-training employment performance, namely the duration of unemployment and employment, we rely on the retrospective monthly employment calendar that gathers detailed information about the individuals labor force status in each month of the previous calendar year. In this questionnaire the individual has to distinguish between up to eight different labor force states for each month. The states include full-time employed, part-time employed, vocational education, short time work, registered unemployed, etc. Information on participation in FRMA comes from a retrospective monthly income calendar that gives detailed information about the income sources in each month of the previous calendar year. Analogues to the employment calendar the individual can give information on up to eleven different income sources for each month. Participation in FRMA is identified by the income information provided about maintenance allowance during further training or retraining.

Due to data restrictions and institutional arrangements (see section 2) we will consider FRMA courses that began during the time span between July 1990 and June 1993. To avoid the need to address early retirement 
issues our selected sample consists of individuals who were not older than 50 in 1990. For the purpose of this study the state unemployment is defined by the item "registered unemployment" in the activity calendar. The state employment comprises the items "full-time employment", "parttime employment", "vocational education" and "short time work" in the retrospective activity calendar. Unemployment (employment) spells are completed if they end through transition into employment (unemployment). In all other cases unemployment (employment) spells are treated as right censored. For methodological reasons, left censored unemployment spells have been excluded from the analysis (see e.g. Vermunt (1997)). The selected sample consists of individuals who had at least one unemployment or employment spell during the time span July 1989 to December $1994 .^{2}$

The different selection criteria used lead to an unbalanced sample of 1632 individuals consisting of 231 trainees and 1401 non-trainees. There are 1761 unemployment spells and 2107 employment spells. 486 (1402) of these unemployment (employment) spells are right censored. The average duration of all unemployment (employment) spells is 8.30 (17.72) months, whereas the average duration of the completed unemployment (employment) spells is 7.03 (12.40) months. By comparing all spells (i.e. including the right-censored spells) and uncensored spells with respect to their average duration the importance of adequately dealing with the problem of censoring becomes obvious. The average duration of the uncensored spells is always lower than the average duration of all spells. Thus the length-bias sampling effect (i.e. short spells will be underrepresented in the sample of right-censored spells) overrides the counter-directional effect that the recorded duration of right-censored spells underestimates their true duration. The 231 trainees participated in 256 training measures. $90.5 \%$ of all trainees participated in only one course during the time span considered. The mean of the course duration is 9.9 months and $20.7 \%$ have a duration of no more than 3 months, $40.2 \%$ of no more than 6 months and $73.0 \%$ of all courses in sample are no longer than 12 months duration.

Figures 2 and 3 focus on a pre- post-training comparison of the em-

\footnotetext{
${ }^{2}$ In order to control for labor market history before participation in FRMA and to measure the employment performance after FRMA participation, we use information on all waves up to 1995. Information on employment status in 1989 (1994) comes form the retrospective calendar in 1990 (1995).
} 
ployment and unemployment duration of trainees. They present product limit estimates of the survivor function for trainees' unemployment (employment) spells that take place before and after the training measure. To inspect whether the difference between the two survivor functions is significant the Wilcoxon and the log-rank test statistics have been computed. ${ }^{3}$ Both tests check the null hypothesis that the two survivor functions (before and after) are the same. Considering first figure 2 which

Figure 2 about here

Figure 3 about here

focuses on the outcome variable unemployment duration we observe that the survivor function for unemployment spells after the training measure lies considerably above the survivor function for unemployment spells before the training measure. Both, the Wilcoxon and the log rank test statistics show that the difference between the two survivor functions is significant. This points to a lengthening effect of training on unemployment duration, i.e. a negative effect on re-employment chances, since trainees remain in unemployment for longer after training than before. For example prior to the training measure the probability of an average trainee remaining unemployed for more than twelve months amounts to $8.5 \%$ while after training it rises to $26.1 \%$. Figure 3 depicts survivor functions for pre- and post-training employment duration. The fact that the survivor function for the post-training employment spells significantly exceeds the survivor function for the pre-training employment spells indicates a positive training effect, i.e. training seems to stabilize (lengthen) the individual employment duration in East Germany.

However there are several aspects which limit such a pre- post-training comparison. Note that the post-training development may not simply be regarded as the result of a positive training effect, because it is not known, how the trainees' post-training labor market situation would have been, had they not participated in the training measure. For example, had the trainees invested more effort into finding a job they might have found one, leading to a similar post-training labor market situation as

\footnotetext{
${ }^{3}$ For illustrative reasons the upper and lower points of the $95 \%$ confidence interval around each survival probability are also given. Note that they only apply to a particular point in time. The connection between the points is strictly speaking not correct.
} 
the one observed in the above figures without the need for training. In addition it can be argued that the post- and pre-training development may also be driven by other time varying factors such as changing individual characteristics (e.g. age) or different demand side conditions due to business cycles. A detailed analysis under which situations a before-after estimator is likely to be biased is given for example by Heckman, Smith (1999).

As is usual for the case of non-experimental data sets the group of nontrainees is not necessarily a suitable comparison or control group for the trainees, since there might be substantial differences between both groups regarding various characteristics other than training. Table 1 shows for a few socio-demographic characteristics in 1991 that there are substantial differences in characteristics such as gender, education or employment status between both groups. Trainees are on average older, more likely to be women and have a higher formal education level than non-trainees. Given the significant differences in characteristics between the group of trainees and the group of non-trainees, it is obvious that post-training differences in the employment performance can not simply be attributed to the effect of the training program.

Table 1 about here

It should be clear that simple approaches like the before-after comparison or the comparison of trainees with the (or a random) group of non-trainees only allow us to evaluate the true (i.e. unbiased) training effect in very specific situations. For the situation given in this study more sophisticated methods that control for a potential selectivity bias with respect to participation in public vocational training need to be considered.

\section{Constructing A CONTROL GROUP USING MATChING METHOdS}

\subsection{The evaluation problem and identifying restrictions}

Inference about the impact of a treatment (in our case participating in a training program) on the response or the outcome of a unit (in our case post-training employment performance of an individual who participated in training) involves speculation about how this unit would have responded, had it not received the treatment (in our case had he/she not participated in a training program). In the econometric and statistical literature it has 
become common to study this kind of problem within a formal framework suggested by Roy (1951) and Rubin (1974) and therefore termed as RoyRubin-Model. In this model there are two potential outcomes $\left(Y^{1}, Y^{0}\right)$ for each individual, where $Y^{1}$ corresponds to the situation with training and $Y^{0}$ without. ${ }^{4}$ Let $D$ be a dummy variable indicating whether an individual actually participated in training $(D=1)$ or not $(D=0)$. Finally to allow for a causal analysis it has to be assumed that cross effects or general equilibrium effects among potential training participants that could occur because of their actual participation are ignored, i.e. the potential outcomes for a given individual are not affected by the training status of other individuals. In the statistical literature this assumption is labeled as the stable unit treatment value assumption (e.g. Rubin $(1978,1991)$ ). The causal training effect for each individual is then defined as the difference between his/her potential outcomes:

$$
\Delta=Y^{1}-Y^{0} .
$$

The fundamental problem of evaluating this causal training effect arises because the observed outcome for each individual is given by

$$
Y=D \cdot Y^{1}+(1-D) \cdot Y^{0}
$$

i.e. depending on the training status we only observe either $Y^{1}$ or $Y^{0}$, but never both. There is always an unobservable component in (1) which, in the literature, is called the counterfactual outcome. Thus the problem of evaluating the causal effect of training is a missing data problem because for any given individual one cannot form the difference in equation (1).

The parameter that receives the most attention in the evaluation literature and which is also considered in this study is the average training effect on the trained. It is defined as:

$$
E(\Delta \mid D=1)=E\left(Y^{1}-Y^{0} \mid D=1\right)=E\left(Y^{1} \mid D=1\right)-E\left(Y^{0} \mid D=1\right) .
$$

This parameter gives an answer to the following question: What is the expected, or mean outcome gain to individuals who participated in the training program compared to the hypothetical situation had they not

\footnotetext{
${ }^{4}$ For recent extensions of this two treatment model (e.g. training vs. no training) to a multiple treatment model with more than two potential states, i.e. where the actual choice set of an individual contains more than two options, for example participating in several distinct training programs such as on-the-job-training vs. off-the-job-training vs. no training see Brodaty, Crépon, Fougére (1999), Imbens (1999), Lechner (1999b, 1999c).
} 
participated? As this question focuses explicitly on actual training participants, it determines the realized gross gain from the training program and is - together with the costs of the program - a central ingredient required to decide whether to continue or terminate the training program (Heckman, Ichimura, Todd (1997, 1998), Heckman, LaLonde, Smith (1999)).

The identification and estimation of the mean treatment effect on the treated is still hampered by the fundamental evaluation problem. Using ordinary observational data, only the first term in the definition of (3) can be identified and estimated consistently from the sample counterparts. In contrast the information necessary to estimate the second (counterfactual) term is unobservable. An intention which is common to many of the approaches described in both the statistical and econometric literature is to estimate the unobservable counterfactual term using the observed outcome information of the non-participants. The estimator which results from taking the mean outcome of non-participants as a proxy is given by

$$
\tau=E\left(Y^{1} \mid D=1\right)-E\left(Y^{0} \mid D=0\right) .
$$

It can be decomposed into two components:

$$
\begin{aligned}
\tau & =\left\{E\left(Y^{1} \mid D=1\right)-E\left(Y^{0} \mid D=1\right)\right\}+\left\{E\left(Y^{0} \mid D=1\right)-E\left(Y^{0} \mid D=0\right)\right\} \\
& =E(\Delta \mid D=1)+B
\end{aligned}
$$

i.e. the true mean training impact in the first curly bracket and a sample selection bias, labeled as $B$, in the second curly bracket (Heckman, Smith (1995)). The estimated training impact only represents the true training impact when the selection bias is zero. The necessary condition for this is given by

$$
E\left(Y^{0} \mid D=1\right)=E\left(Y^{0} \mid D=0\right),
$$

i.e. when the expected potential outcome without training is equal for both, the group of participants and the group of non-participants, there will be no selection bias. In practice this condition will fail to hold under a number of plausible circumstances, most likely if trainees and non-trainees have systematic differences in their individual characteristics as they do in our data set (see section 3 ).

In this study we follow an approach introduced by Rubin (1977) to cope with the evaluation problem described above. To construct an adequate 
control group the identifying assumption is imposed, that conditional on all relevant covariates $(Z)$, the potential outcome without training $\left(Y^{0}\right)$ is independent of the assignment to training $(D)$. The implementation of conditioning on all relevant covariates is however limited in case of a high dimensional vector $Z$. To deal with this dimensionality problem, Rosenbaum and Rubin (1983) suggest the use of the propensity score, i.e. the conditional probability of participating in training given the set of all relevant covariates, defined as $P(Z=z) \equiv P(D=1 \mid Z=z)$. They show that if the potential outcome without training is independent of the assignment mechanism conditional on $Z=z$, then the conditional independence assumption can be extended to the use of the propensity score:

$$
Y^{0} \amalg D \mid P(Z) .
$$

As a consequence

$$
E\left(Y^{0} \mid P(Z), D=1\right)=E\left(Y^{0} \mid P(Z), D=0\right),
$$

which allows us to rewrite the crucial term in the mean training effect as

$$
E\left(Y^{0} \mid D=1\right)=E_{P(Z)}\left[E\left(Y^{0} \mid P(Z), D=0\right) \mid D=1\right]
$$

Note that the outer expectation is taken over the distribution of the propensity score in the treated population. The major advantage of the identifying assumption (6) is that it turns the estimation problem into a much easier task since one only has to condition on a univariate scale, i.e. on the propensity score. In order to condition on the propensity score the next step has to be the estimation of this propensity score. This is done in subsections IV.2. by means of a panel probit model. Since we aim to construct an adequate control group that does not contain systematically different characteristics from those of the trainee group an appropriate way to condition on the estimated propensity score is to apply matching methods proposed by Rosenbaum and Rubin (1985) and Rubin (1991).

\subsection{A panel probit model for the estimation of the propensity score}

The estimation of the propensity score is a key element of the approach used to overcome the fundamental evaluation problem. This estimation has to take into account that the starting dates of the FRMA courses vary over time among the participants, i.e. we are not evaluating one specific 
program that originated at one specific date, but rather different starting dates exist among the training participants. This fact is important to this study because if relevant time varying covariates exist which are related to the beginning of the training program, then they are not clearly defined for the non-trainees (Lechner (1999a)).

Lechner (1999a, 2000) solves this problem of adequately dating time varying covariates when estimating the propensity score by using characteristics from the beginning of the observation period to explain all subsequent participation decisions, i.e. he chooses covariates based on the individual's interview of 1990 to explain whether that individual participated in public vocational training up to early 1993. Thus the estimation of a simple cross-sectional probit model is sufficient to solve the problem. The main weakness of such an approach obviously is that the distance between the date of measuring the covariates and the possible beginning of a training course may become very large, in this case the distance could range between 1 month and 3 years. In such a situation the question arises whether these covariates are informative enough to explain a training participation which took place up to 3 years later.

In this study we choose a different solution to the problem of adequately dating time-varying covariates (see e.g. Hujer, Maurer, Wellner (1999)). The idea is to estimate a panel probit model. Let the relevant covariates $\left(z_{i t}\right)$ of an individual $i$ refer to $t$, the date of the interview in each year. The dependent variable $D_{i t}$ is defined as the beginning of an actual training participation within the interval $(t, t+1]$, i.e. whether the individual is observed as having entered a FRMA course at some time between two consecutive interviews. According to this definition the time-varying covariates are well defined for the non-trainees and always dated close to but prior to the beginning of a possible training participation.

The panel probit model which will be used to estimate the propensity score takes the following well known form:

$$
D_{i t}^{*}=z_{i t}^{\prime} \beta+u_{i t} \quad i=1, \ldots, n ; t=1, \ldots, T,
$$

where the $i$ subscript indicates the individuals of a cross-section and the $t$ subscript the time period. $z_{i t}$ is the $m$-dimensional vector of relevant 
pre-training covariates and $\beta$ a corresponding parameter vector. $u_{i t}$ is an unobserved disturbance and $D_{i t}^{*}$ the latent continuous dependent variable. The relationship between $D_{i t}^{*}$ and the observed training participation $D_{i t}$ is given as follows:

$$
D_{i t}=I\left[D_{i t}^{*}>0\right]=I\left[z_{i t}^{\prime} \beta+u_{i t}>0\right]
$$

where $I$, the indicator function equals one if the expression in the brackets is true and zero otherwise. In matrix notation the model is written as

$$
D_{i}=I\left[z_{i}^{\prime} \beta+u_{i}>0\right]
$$

where $z_{i}=\left(z_{i 1}, \ldots, z_{i T}\right)^{\prime}, u_{i}=\left(u_{i 1}, \ldots, u_{i T}\right)^{\prime}$ and $D_{i}$ is the $(T \times 1)$ vector of observed training participation of individual $i$. To complete the specification let $s_{i}=\left(D_{i}, z_{i}\right)$ be a realization of $n$ independent random draws of the joint distribution of a corresponding pair of random variables. Moreover, it is assumed that the error terms are jointly normally distributed $u_{i} \sim$ iid $N(0, \Sigma)$ and independent of the explanatory variables $z_{i}$. The latter assumption implies that the $z_{i}$ are strictly exogenous. In order to ensure identification of $\beta$ only one main-diagonal element of the intertemporal error covariance matrix $(\Sigma)$ has to be set to unity (Heckman (1981)). However, as we are only interested in scaled estimates of $\beta$ it is assumed that all main diagonal elements of $\Sigma$ equal one (e.g. Avery, Hansen, Hotz (1983)).

To estimate the above model we adopt the generalized method of moments (GMM) approach based on conditional moment restrictions as suggested by Newey $(1990,1993)$ for a general class of nonlinear estimators and adapted to the panel probit model for example by Bertschek, Lechner (1998) and Inkmann (1999). We use a particular variant of this estimator that is based on a nonparametric estimation of the optimal set of instruments. As shown by the latter authors in Monte Carlo studies, this estimator turns out to have better properties than its potential competitors, namely the widely used maximum likelihood (ML) estimator with equicorrelated residuals (known as random effects specification) or an estimation based on the Simulated Maximum Likelihood (SML) technique.

The selection of relevant covariates for the panel probit model relies on theoretical hypotheses related to human capital theory. Moreover we have to consider the institutional arrangements which are relevant for the labor 
offices when choosing training participants. According to the regulations of the Work Support Act applicants for further training and retraining which is supported through a maintenance allowance are selected on the grounds of their education, employment history, job specific qualifications, other qualifications, personal situation, motivation with respect to a training measure and motivation with respect to a future employment. Finally, an effort is made to proceed in accordance with relevant variables suggested in other empirical studies on training participation (e.g. Blundell, Dearden, Meghir (1994)).

Table 2 shows the GMM estimates of the unbalanced panel probit for participation in FRMA (for definitions of the variables see table A.1 in appendix). In contrast to human capital theory no significant age influence on the participation probability is observable. This is not surprising if one considers that in the first few years of the transformation process the labor force in general had to be adjusted to the new requirements of a western style economy. Consequently training was an equally important investment into human capital for older and younger individuals alike. This point is emphasized by the age profile of training participants which reveals that they are older than non-trainees (see section 3, table 1). Given that during the post-unification period women suffered far more from unemployment than men did, it is hardly surprising to find that they are more likely to participate in a public vocational training measure. Variables describing family situation such as martial status (PartHH) or women with children (Female $\times$ Kids) do not appear to have influenced the training probability.

Variables capturing schooling (Abitur) and occupational degrees (Lehre, Diplom) are significantly positive indicating that earlier accumulated human capital positively influenced readiness to invest in new human capital during the transformation process. This result also stands in line with the descriptives in section 3 according to which trainees have an above average schooling and vocational education. Turning our attention to variables that reflect actual labor market history prior to training we observe that the status of being unemployed significantly increases participation probability. Different temporal labor force dynamics patterns are also important participation predictors. Compared to individuals who were employed for at least the last eleven months prior to the month in 
which the interview took place (reference category) those whose employment was recently discontinued (Emp $\rightarrow$ Unm, Emp $\rightarrow$ OLF) have an increased participation probability, while those who recently managed to find an employment have a reduced participation probability (Unm $\rightarrow$ Emp).

No evidence is found that that the status of being employed at the date of the interview (Employed) and in particular variables associated with job position (BluCollar, WhiCollar) affect participation in public vocational training. An individual working in the occupation he/she was originally educated for (JobEduc) does not have a reduced probability of participation. Considering the many firms that were not able to survive under the new economic circumstances there was a general threat of unemployment and thus a nearly equal potential necessity existed for everybody to participate in training irrespectively of whether he/she was working in an occupation that he/she was originally educated for or not.

Individuals who are currently highly satisfied with life in general (SatisLife) are less likely to participate in a public vocational training measure while the fact that an individual is not currently employed but seeking an employment in the future (FutEmpDes) does not predict the participation decision. Regarding the macroeconomic factors that might affect training participation we find that the regional labor market conditions (RegSituation) had no influence while the yearly dummies proved to be significant. Compared to the reference year of 1992 a significant positive effect for 1991 is observable. This result also stands in line with the official numbers on entries into further training and retraining.

Table 2 about here

\subsection{Application of matching methods}

The aim of the matching method is to select for each trainee non-trainees, that resemble him/her as accurately as possible in terms of pre-training characteristics and thus to achieve a conditional independence between the potential outcome without training $\left(Y^{0}\right)$ and the decision to participate in training $(D)$. If this is done correctly, we obtain a matched sample consisting of trainees and controls who, on average, - similar to a randomized experiment - do not systematically differ in any relevant characteristics. 
Thus, we eliminate the need to take the selection process into training into account when estimating its impact on individual employment performance.

The matching algorithm that will be applied in this study (see appendix table A.2) is based on one proposed by Rosenbaum, Rubin (1985) and Rubin (1991). They find that this kind of algorithm appears to produce the best match quality or bias reduction in terms of balancing the covariates in the group of trainees and matched non-trainees. Similar matching algorithms have been applied by Lechner (1999a, 2000) and Hujer, Maurer, Wellner (2000) for the evaluation of training measures in East and West Germany, respectively. The central conditioning (matching) variable is the estimated propensity score. Along the lines of Lechner (1999a, 2000) the unbounded score $z_{i t}^{\prime} \hat{\beta}$ is used as the main matching variable instead of the bounded propensity score $\Phi\left(z_{i t}^{\prime} \hat{\beta}\right)$. Due to the location and symmetry of the distribution of $z_{i t}^{\prime} \hat{\beta}$ the use of $\Phi\left(z_{i t}^{\prime} \hat{\beta}\right)$ would lead to an undesirable asymmetry when $\Phi\left(z_{i t}^{\prime} \hat{\beta}\right)$ is close to 0 or 1 .

For each trainee the confidence interval around the propensity score is used to select a subset of non-trainees who are very similar. Like Lechner (2000) we do not use a fixed confidence interval width (caliper width), but instead allow the width to vary individually with the precision of the estimation of the propensity score. If no non-trainee can be found with a propensity score in the range of the trainee's confidence interval, there is obviously a lack of common support (see e.g. Heckman, Ichimura, Todd (1997)). Hence we do not further consider this trainee in our training evaluation. This is different to the matching procedures suggested by Rosenbaum, Rubin (1985) and Lechner (1999a, 2000). In such a case their matching procedure chooses the non-trainee with the nearest available propensity score. However, if the closest available non-trainee is very different to the trainee this might strongly decrease the match quality. Proceeding this way thus stands in contrast with the requirement that matching only produces meaningful results within the region of common support (Heckman, Ichimura, Smith, Todd $(1996,1998))$.

The estimation of the propensity score incorporates characteristics that are all based on the date of the yearly interview. As a result potentially important differences such as a particularly bad labor market situation for 
trainees just prior to the public vocational training course, as emphasized by Lechner (1999a, 2000) for different types of training in East Germany or by studies like Ashenfelder, Card (1985) or Card, Sullivan (1988) for the training measures in the US, might not be captured adequately. To account for these differences the matching procedure is extended to include a set of variables obtained from the retrospective calendar which describes the monthly employment history just prior to the beginning of a trainee's training measure. These additional match variables consist of the unemployment and employment status in the last month before training as well as the average unemployment and employment rates for the last 4 and 12 months prior to training. Inclusion of such variables in the estimation of the propensity score is impossible because the relevant date is unknown for non-trainees. To further enhance its matching quality, the matching procedure also directly incorporates a subset of variables that were used in the propensity score estimation. These variables are: Female, Diplom and BlueCollar. Having found a subset of non-trainees that fall into the propensity score confidence interval for a given trainee, nearest available Mahalanobis metric matching (for the propensity score and the additional match variables) is used to select the closest non-trainee.

In principal it seems straightforward to match each trainee with only the closest non-trainee (one-to-one sampling). Thus the matching procedure is finished when for every trainee one non-trainee has been found. However, neglecting the other non-trainees leads to a small sample size and hence to low degrees of freedom when estimating the impact of training on individual employment performance. To increase efficiency we can extend the one to one sampling to an oversampling matching procedure that incorporates information about other non-trainees who also closely resemble the trainees with respect to the relevant matching variables. In the case of oversampling the matching procedure is repeated a number of times in order to find further non-trainees for each valid trainee. Of course compared to the one to one sampling the drawback arises that the match quality and thus bias reduction declines when matching further non-trainees to each trainee. Note, however that an estimator with a slightly higher bias but a significantly smaller variance may of course be preferable to an unbiased estimator whose variance is very large (Rubin (1977)). In essence we are facing a typical bias-variance trade-off. In general it is 
difficult to determine which point on the trade-off is desired. Whether additional non-trainees can be matched to each trainee obviously strongly depends on the size of the non-trainee pool and on the overlap in the distribution of the propensity score between the trainee and non-trainee group.

Figure 4 depicts the distributions of the (unbounded) propensity scores for both, the group of participants and non-participants. A comparison of the distributions of $z^{\prime} \hat{\beta}$ reveals that despite the

Figure 4 about here

mass of the distribution for the non-trainees being to the left of the trainees' the requirement of a complete a-priori overlap is fulfilled. Two adequate control groups will be constructed: One to estimate the effects of training on the post-training unemployment duration, the other to evaluate the effects on post-training employment duration. In order to find the adequate control group we always consider five matching procedures, namely the one to one sampling and the four different oversampling procedures (see table A.3 and A.4 in the appendix).

\section{Publicly SPONSORED VOCATIONAL TRAINING POST-TRAINING EMPLOYMENT PERFORMANCE}

This section considers the unemployment and employment durations as the relevant post-training outcome variables. The first matched sample consists of 142 trainees for whom we observe 187 post-training unemployment spells and of 142 non-trainees for whom 168 post-training unemployment spells can be observed, the second one contains 123 trainees contributing 159 post-training employment spells and 242 non-trainees for whom we observe 291 post-training employment spells.

One way to assess the impact of public vocational training on unemployment (employment) duration would be to compare the mean posttraining unemployment (employment) duration of trainees and matched non-trainees. Yet, as Ham, LaLonde $(1990,1996)$ demonstrate in an experimental framework which eliminates the necessity to control for selection into training by randomization, the estimation technique required to evaluate an unbiased training effect depends heavily on the particular outcome of 
interest. If the outcome of interest is the unemployment rate, it is perfectly sufficient to compare trainees' and controls' post-training average unemployment rates. However, if the focus is on the unemployment or employment duration as it is here, there are three reasons why a simple comparison of trainees' and controls' average duration would be insufficient and would lead to potentially biased estimates of the training effect:

- The first problem associated with comparing the trainees' and controls' average unemployment and employment duration is the existence of right censored spells.

- A second problem is that trainees' and controls' unemployment (employment) spells do not necessarily originate at the same time and consequently time dependent characteristics (e.g. age) and demand conditions might differ.

- Finally due to a selective nature of duration data it is necessary to take into account all other observable and unobservable characteristics that might affect the transition rate into unemployment or employment.

These issues emphasize that even with a matched sample it is required to additionally rely on an econometric model. An appropriate approach which considers right censoring, and can take into account other observable and unobservable characteristics than training that also influence the unemployment (employment) duration, is a hazard rate model.

As the duration in the GSOEP data is only available on a monthly basis, it is not appropriate to apply a model based on the notion of continuous time. When using continuous time models with grouped duration data, a term used by Kiefer (1988), parameter estimates could be meaningless due to the existence of ties, i.e. equal durations for different observations (e.g. Kalbfleisch, Prentice (1980), Cox, Oakes (1984)). Assuming that duration data are grouped into $J+1$ intervals with the $j$-th interval defined as $\left[t_{j}, t_{j+1}\right), j=0,1, \ldots, J$, the discrete hazard rate for an arbitrary $j$ is defined as the probability that a spell ends before $t_{j+1}$, given that it has lasted until $t_{j}$. The discrete hazard rate can be expressed in terms of the survivor function $S_{i}$ as:

$$
h_{i}(j)=P\left[T_{i}<t_{j+1} \mid T_{i} \geq t_{j}\right]=\frac{S_{i}\left(t_{j}\right)-S_{i}\left(t_{j+1}\right)}{S_{i}\left(t_{j}\right)} .
$$


$T_{i}$, the duration time of observatory $\mathrm{i}$, is a continuous non-negative random variable with realization $t$. If we assume that changes in the covariates $x_{i}(t)$ only occur at the lower bounds of each interval $j$, i.e. the covariates are constant within each interval, and substituting $\gamma_{j}=\ln \int_{t_{j}}^{t_{j+1}} \lambda_{0}(u) d u$, then the survivor function takes the following form:

$$
\begin{aligned}
S_{i}\left(t_{j} \mid \omega_{i}\right) & =\exp \left(-\sum_{m=0}^{j-1} \int_{t_{m}}^{t_{m+1}} \lambda_{0}(u) \exp \left(x_{i}^{\prime}\left(t_{m}\right) \beta\right) \exp \left(\omega_{i}\right) d u\right) \\
& =\exp \left(-\exp \left(\omega_{i}\right) \sum_{m=0}^{j-1} \exp \left[\left(x_{i}^{\prime}\left(t_{m}\right) \beta\right)+\gamma_{m}\right]\right) .
\end{aligned}
$$

$\lambda_{0}$ denotes the baseline hazard rate, $\omega$ takes account of unobserved heterogeneity, $\beta$ is the vector of coefficients to be estimated and $\gamma_{m}=$ $\ln \int_{t_{m}}^{t_{m+1}} \lambda_{0}(u) d u$. To obtain $S_{i}\left(t_{i}\right)$ we assume that $\exp \left(\omega_{i}\right)=\tau_{i}$ follows a gamma distribution with mean one and variance $\sigma^{2}$. Let $f\left(\tau_{i}\right)$ denote the corresponding density function, then the integration with respect to $\tau_{i}$ leads to:

$$
\begin{aligned}
S_{j}\left(t_{j}\right) & =\int_{0}^{\infty} \exp \left(-\tau_{i} \sum_{m=0}^{j-1} \exp \left[\left(x_{i}^{\prime}\left(t_{m}\right) \beta\right)+\gamma_{m}\right]\right) f\left(\tau_{i}\right) d \tau_{i} \\
& =\left(1+\sigma^{2} \cdot \sum_{m=0}^{j-1} \exp \left[\left(x_{i}^{\prime}\left(t_{m}\right) \beta\right)+\gamma_{m}\right]\right)^{\sigma^{-2}}
\end{aligned}
$$

To derive the resulting likelihood function we define a dummy variable $\delta_{i}$ indicating whether the $i$-th spell is right censored $\left(\delta_{i}=0\right)$ or not $\left(\delta_{i}=1\right)$. For a sample of $N$ spells we then obtain the the following log-likelihood:

$$
\begin{aligned}
l\left(\gamma, \beta, \sigma^{2}\right)= & \sum_{i=1}^{N} \ln \left\{\delta_{i} \cdot\left[1+\sigma^{2} \cdot \sum_{m=0}^{j-1} \exp \left(x_{i}^{\prime}\left(t_{m}\right) \beta+\gamma_{m}\right)\right]^{-\sigma^{-2}}\right. \\
& \left.+\left(1-2 \delta_{i}\right) \cdot\left[1+\sigma^{2} \cdot \sum_{m=0}^{j} \exp \left(x_{i}^{\prime}\left(t_{m}\right) \beta+\gamma_{m}\right)\right]^{-\sigma^{-2}}\right\} .
\end{aligned}
$$

Similar models have already been applied by Meyer $(1987,1990)$ and Narendranathan, Stewart (1993) to assess the impact of unemployment benefits on unemployment duration.

Because the interest of this study focuses on the effects of public vocational training measures on unemployment and employment duration the complete estimation results of the hazard rate model for unemployment and employment duration have been referred to the appendix (Table A.5 and A.6). The following discussion will concentrate on the parameter estimates that describe the causal effects of participating in a FRMA measure. In the 
context of an hazard rate model describing the unemployment or employment duration the training effect could, in principle, be measured by a single indicator variable that equals one if the individual participated in training and zero if not:

TR: individual has participated in a public vocational training course at sometime prior to the current spell ( $1=$ yes, $0=$ otherwise).

However the estimated parameter of this indicator variable may capture a rather heterogeneous training effect. Therefore we have tried to determine whether any heterogeneous effects of public vocational training on posttraining unemployment or employment duration are related to the duration of the training measure. Two additional indicator variables have been included in the hazard rate model to capture public vocational training courses that lasted for longer than six months (long courses) or for between four and six months (medium courses). Consequently the reference category refers to short courses lasting no longer than three months:

TR_Dur1-3: short courses, that lasted for no longer than three months (reference category).

TR_Dur4-6: medium courses, that lasted for between four and six months ( $1=$ yes, $0=$ otherwise).

TR_Dur7+: long courses, that lasted for longer than six months $(1=$ yes, $0=$ otherwise).

Besides considering differences in the course duration an attempt is made here to take into account any influence the post-training timing of the unemployment spell might have on the effectiveness of the training measure to be considered. In this respect, the distance between the end of the training course and the beginning of the post-training unemployment (employment) spell may be a relevant factor and therefore two further indicators are incorporated in the hazard rate model. ${ }^{5}$ The first indicator variable focuses on unemployment (and employment) spells that begin within a time period of between two to twenty four (twelve) months after the conclusion of training, while the second indicator variable refers to unemployment (employment) spells that begin no earlier than two (one) years after the training measure

\footnotetext{
${ }^{5}$ Another possibility, considered by Gritz (1993), would be to differentiate between the first unemployment (employment) spell after training and any subsequent spells.
} 
ends. Note that the reference category to these two post-training timing variables covers unemployment (employment) spells that take place immediately after the training course, i.e. if the trainee becomes unemployed (employed) in the first month after the training course ends:

TR_1: the post-training unemployment (employment) spell begins immediately, i.e. in the first month after the training course ends (reference category).

TR_2-12: the post-training unemployment (employment) spell begins within a time period of between two and twelve months after the conclusion of training ( $1=$ yes, $0=$ otherwise).

TR_13+: the post-training unemployment (employment) spell begins no earlier than two years (one year the in case of East Germany) after the training course ends ( $1=$ yes, $0=$ otherwise).

Table 3 presents the estimated training effects obtained from a maximum likelihood estimation of the discrete hazard rate model with unobserved heterogeneity for unemployment duration and employment duration. The numbers in the non-gray hatched square represent the nine possible compound training effects. These allow for a differentiated analysis of the effects of a FRMA measure on unemployment or employment duration.

Table 3 about here

Additionally the marginal effects of a different course duration and of a different post-training unemployment or employment spell timing are presented in the gray hatched column and row respectively. These marginal effects always have to be interpreted with respect to their relevant reference category and cannot be interpreted in relationship to not participating in training. Turning now to the estimation results for unemployment duration we find that participating in a FRMA measure does not significantly decrease the post-training unemployment duration (increases post-training reemployment chances) irrespective of the training course duration or the timing of the post-training unemployment spell. However, the signs of the compound training effects indicate that short courses might be more helpful than longer ones. A claim that is supported if we look at the marginal effects on the course duration. It is found that training measures lasting more than six months are significantly less effective than short courses of a duration of 
no longer than 3 months. This could be seen as a very weak hint that at least short courses such a the ones according to 41a AFG might have helped unemployed training participants in East Germany to increase their reemployment chances during the post-unification transformation process. The estimation results for employment duration show that with regards to the compound training effect the results are just like they are in the case of unemployment duration: Participation in a FRMA measure has no significant impact on the duration of any subsequent employment spell. Moreover if we consider the marginal effects we even find - in contrast to the case of unemployment duration - that the effect of public vocational training measures on employment stability does not significantly vary with respect to the course duration. Summing up the results of this section, no evidence is found to suggest that participation in FRMA either decreases unemployment duration or increases employment duration. There is only a very weak hint that at least short courses seem to be more effective at reducing unemployment duration than longer ones are.

\section{Conclusion}

In this study we have assessed the impact of public sector sponsored vocational training on individual employment performance in East Germany. To solve the fundamental evaluation problem, i.e. to construct an adequate control group, in the context of a non-experimental data set we rely on matching methods. Matching methods restrict themselves to the situation in which selection into training occurs only on the basis of observable characteristics. This assumption seems credible given that we base our analysis on a very informative data set. A comparison between the group of trainees and matched non-trainees reveals that our matching procedure eliminates the systematic differences that exist between random non-trainees and trainees. This is a central requirement in order to obtain credible training estimates that are not affected by sample selection bias. The different labor market outcomes which have been considered are the unemployment and employment duration. The evaluation of training effects on duration requires the use of an econometric model that takes into account -amongst other problems- the censoring of the outcome variable (Ham, LaLonde $(1990,1996)$ ). 
Regarding the outcome variables unemployment duration or employment duration public vocational training measures did not have any significant effect at all neither positive nor negative. This raises the question whether training in East Germany was ineffective because the labor market conditions are insufficient, the courses are of a low quality or training was not adequately targeted to individuals. Along these lines it would be interesting to investigate whether positive training effects are obtained when the training measures are further differentiated by other characteristics than course duration, e.g. provider, intensity or topics. Unfortunately, the low number of trainees in the GSOEP as well as the fact that further information on course characteristics is not available in the data did not allow such an analysis in this study. 


\section{REFERENCES}

[1] Ashenfelter, O. (1978): Estimating the Effects of Training Programs on Earnings. Review of Economics and Statistics 60, 47-57.

[2] Ashenfelter, O., Card, D. (1985): Using the Longitudinal Structure of Earnings to Estimate the Effect of Training Programs. Review of Economics and Statistics 67, 648-660.

[3] Avery, R., Hansen, L.P., Hotz, V. (1983): Multiperiod Probit Model and Orthogonality Condition Estimations. International Economic Review 24, 21-35.

[4] Bertschek, I., Lechner, M. (1998): Convenient Estimators for the Panel Probit Model. Journal of Econometrics 87, 329-371.

[5] Blundell, R., Dearden, L., Meghir, C. (1994): The Determinants and Effects of Work Related Training in Britain. Working Paper, Institute for Fiscal Studies, London.

[6] Brodaty, T., Crépon, B., Fougère, D. (1999): Using Matching Estimators to Evaluate Alternative Youth Employment Programs: Evidence from France, 1986-1988, Working Paper.

[7] Card, D., Sullivan, D. (1988): Measuring the Effect of Subsidized Training Programs on Movements in and out of Employment. Econometrica $56,497-530$.

[8] Cox, D.R. (1972): Regression Models and Life-Tables (with Discussion). Journal of the Royal Statistical Society (Series B) 34, 187-220.

[9] Cox, D.R., Oakes, D. (1984): Analysis of Survival Data. Chapman and Hall, London.

[10] Dehejia, R.H., Wahba, S. (1998a): Propensity Score Matching Methods for Non-Experimental Causal Studies. NBER Working Paper 6829.

[11] Dehejia, R.H., Wahba, S. (1998b): Causal Effects in Non-Experimental Studies: Re-Evaluating the Evaluation of Training Programs. NBER Working Paper 6586.

[12] Elbers, C., Ridder, G. (1982): True and Spurious Duration Dependence: The Identifiability of the Proprotional Hazard Model. Review of Economic Studies 49, 403-409. 
[13] Fitzenberger, B., Prey, H. (1996): Training in East Germany: An Evaluation of the Effect on Employment and Wages. Discussion Paper 361996, Center for International Labor Economics, Universität Konstanz.

[14] Fitzenberger, B., Prey, H. (1997): Assessing the Impact of Training on Employment - The Case of East Germany. ifo-Studien 43, 71-116.

[15] Gritz, M.R. (1993): The Impact of Training on the Frequency and Duration of Employment. Journal of Econometrics 57, 21-51.

[16] Ham, J.C., LaLonde, R.J. (1990): Using Social Experiments to Estimate the Effect of Training on Transition Rates. In: Hartog, J., Ridder, G., Theeuwes, J. (Eds.): Panel Data and Labor Market Studies. NorthHolland, Amsterdam, 157-172.

[17] Ham, J.C., LaLonde, R.J. (1996): The Effect of Sample Selection and Initial Conditions in Duration Models: Evidence from Experimental Data on Training. Econometrica 64, 175-205.

[18] Hanefeld, U. (1987): Das Sozio-ökonomische Panel - Grundlagen und Konzeption. Campus Verlag, Frankfurt am Main.

[19] Heckman, J.J. (1981): Statistical Models for Discrete Panel Data. In: Manski, C.F., McFadden, D. (Eds.): Structural Analysis of Discrete Data with Econometric Applications, MIT-Press, Cambridge, 114-178.

[20] Heckman, J.J., Hotz, J. (1989): Choosing Among Alternative Nonexperimental Methods for Estimating the Impact of Social Programs: The Case of Manpower Training. Journal of the American Statistical Association 84, 862-880.

[21] Heckman, J.J., Ichimura, H., Smith, J.A., Todd, P. (1996): Sources of Selection Bias in Evaluating Social Programs: An Interpretation of Conventional Measures and Evidence on the Effectiveness of Matching as a Program Evaluation Method. Proceedings of the National Academy of Science 93, 13416-13420.

[22] Heckman, J.J., Ichimura, H. Smith, J.A., Todd, P. (1998): Characterizing Selection Bias Using Experimental Data. Econometrica 66, 10171098. 
[23] Heckman, J.J., Ichimura, H., Todd, P. (1997): Matching As An Econometric Evaluation Estimator: Evidence from Evaluating a Job Training Programme. Review of Economic Studies 64, 605-654.

[24] Heckman, J.J., Ichimura, H., Todd, P. (1998): Matching As An Econometric Evaluation Estimator. Review of Economic Studies 65, 261-294.

[25] Heckman, J.J., LaLonde, R.J., Smith, J.A. (1999): The Economics and Econometrics of Active Labor Market Programs. In: Ashenfelter, O.C., Card, D. (Eds.): Handbook of Labor Economics, Vol. 3A. NorthHolland, Amsterdam, 1865-2097.

[26] Heckman, J.J., Robb, R. (1985): Alternative Methods for Evaluating the Impact of Interventions. In: Heckman, J.J., Singer, B. (Eds.): Longitudinal Analysis of Labor Market Data. Cambridge University Press, Cambridge, 156-245.

[27] Heckman, J.J., Singer, B. (1984): A Method for Minimizing the Impact of Distributional Assumptions in Econometric Models for Duration Data. Econometrica 52, 271-320.

[28] Heckman, J.J., Smith, J.A. (1995): Assessing the Case for Social Experiments. Journal of Economic Perspectives 9, 85-110.

[29] Heckman, J.J., Smith, J.A. (1999): Ashenfelter's Dip and the Determinants of Participation in a Social Program: Implications for Simple Program Evaluation Strategies. Working Paper, University of Chicago.

[30] Hujer, R., Maurer, K.-O., Wellner, M. (1999): The Effects of Public Sector Sponsored Training on Unemployment Duration in West Germany - A Discrete Hazard Rate Model Based on a Matched Sample. ifo-Studien. 45. 371-410.

[31] Hübler, O. (1997): Evaluation beschäftigungspolitischer Massnahmen in Ostdeutschland. Jahrbücher für Nationalökonomie und Statistik 216, 21-44.

[32] Imbens, G. (1999): The Role of the Propensity Score in Estimating Dose-Response Functions. NBER Technical Working Paper 237.

[33] Inkmann, J. (1999): Misspecified Heteroskedasticity in the Panel Probit Model: A Small Comparison of GMM and SML Estimators. Forthcoming in: Journal of Econometrics. 
[34] Kalbfleisch, J., Prentice, R. (1980): The Statistical Analysis of Failure Time Data. John Wiley \& Sons, New York.

[35] Kiefer, N.M. (1988): Analysis of Grouped Duration Data. In: Prabhu, N.U. (Ed.): Statistical Inference from Stochastic Processes. Contemporary Mathematics 80, American Mathematical Society, Providence, 107-137.

[36] Kraus, F., Puhani, P., Steiner, V. (1999): Employment Effects of Publicly Financed Training Programmes: The East German Experience. Jahrbücher für Nationalökonomie und Statistik 219, 216-248.

[37] LaLonde, R.J. (1986): Evaluating the Econometric Evaluations of Training Programs with Experimental Data. American Economic Review 76, 604-620.

[38] Lancaster, T. (1990): The Econometric Analysis of Transition Data. Cambridge University Press, Cambridge.

[39] Lechner, M. (1999a): Earnings and Employment Effects of Continuous Off-the-Job Training in East Germany after Unification. Journal of Business \& Economic Statistics 1, 74-90.

[40] Lechner, M. (1999b): Identification and Estimation of Causal Effects of Multiple Treatments under the Conditional Independence Assumption. Discussion Paper 9908, Volkswirtschaftliche Abteilung, Universität St. Gallen.

[41] Lechner, M. (1999c): Programme Heterogeneity and Propensity Score Matching: An Application to the Evaluation of Active Labour Market Policies. mimeo.

[42] Lechner, M. (2000): An Evaluation of Public Sector Sponsored Continuous Vocational Training Programs in East Germany. Forthcoming in: The Journal of Human Resources.

[43] Lechner, M., Breitung, J. (1996): Some GMM Estimation Methods and Specification Tests for Nonlinear Models. In: M ty s, L., Sevestre, P. (Eds.): The Econometrics of Panel Data, $2^{\text {nd }}$ edition, Dordrecht, 583-612. 
[44] Meyer, B.D. (1987): Hazard and Markov Chain Models with Applications to Labor Economics. Unpublished Ph.D. Thesis, Massachusetts Institute of Technology, Cambridge.

[45] Meyer, B.D. (1990): Unemployment Insurance and Unemployment Spells. Econometrica 58, 757-782.

[46] Narendranathan, W., Stewart, M.B. (1993): How Does the Benefit Effect Vary as Unemployment Spells Lengthen? Journal of Applied Econometrics 8, 361-381.

[47] Newey, W.K. (1990): Efficient Instrument Variables Estimation of Nonlinear Model. Econometrica 58, 809-837.

[48] Newey, W.K. (1993): Efficient Estimation of Models with Conditional Moment Restrictions. In: Maddala, G.S., Rao, C.R., Vinod, H.D. (Eds.): Handbook of Statistics 11, North Holland, Amsterdam, 419454.

[49] Pannenberg, M. (1995): Weiterbildungsaktivitäten und Erwerbsbiographie. Campus Verlag, Frankfurt am Main. Projektgruppe Sozio-Ökonomisches Panel (1998): Funktion und Design einer Ergänzungsstichprobe für das Sozio-ökonomische Panel (SOEP). DIW Diskussionspapiere 163, Deutsches Institut für Wirtschaftsforschung, Berlin.

[50] Rosenbaum, P.R., Rubin, D.B. (1983): The Central Role of the Propensity Score in Observational Studies for Causal Effects. Biometrika 70, 41-55.

[51] Rosenbaum, P.R., Rubin, D.B. (1985): Constructing a Control Group Using Multivariate Matched Sampling Methods that Incorporate the Propensity Score. The American Statistician 39, 33-38.

[52] Roy, A.D. (1951): Some Thoughts on the Distribution of Income. Oxford Economic Papers 2, 135-146.

[53] Rubin, D.B. (1974): Estimating Causal Effects of Treatments in Randomized and Nonrandomized Studies. Journal of Educational Psychology $66,688-701$.

[54] Rubin, D.B. (1977): Assignment to a Treatment Group on the Basis of a Covariate. Journal of Educational Statistics 2, 1-26. 
[55] Rubin, D.B. (1978): Bayesian Inference for Causal Effects. Annals of Statistics 6, 34-58.

[56] Rubin, D.B. (1991): Practical Implications of Modes of Statistical Inference for Causal Effects and the Critical Role of the Assignment Mechanism. Biometrica 47, 1213-1234.

[57] Staat, M. (1997): Empirische Evaluation von Fortbildung und Umschulung. Nomos Verlagsgesellschaft, Baden-Baden.

[58] Trussell, J., Richards, T. (1985): Correcting for Unmeasured Heterogeneity in Hazard Models Using the Heckman-Singer Procedure. In: Tuma, N.B. (Ed.): Sociological Methodology 1985. Jossey-Bass, San Francisco, 242-276.

[59] Vermunt, J.K. (1997): Log-Linear Models for Event Histories. Sage Publications, Thousand Oakes.

[60] Wagner, G.G., Burkhauser, R.V., Behringer, F. (1993): The English Language Public Use File of the German Socio-Economic Panel. Journal of Human Resources 28, 429-433. 


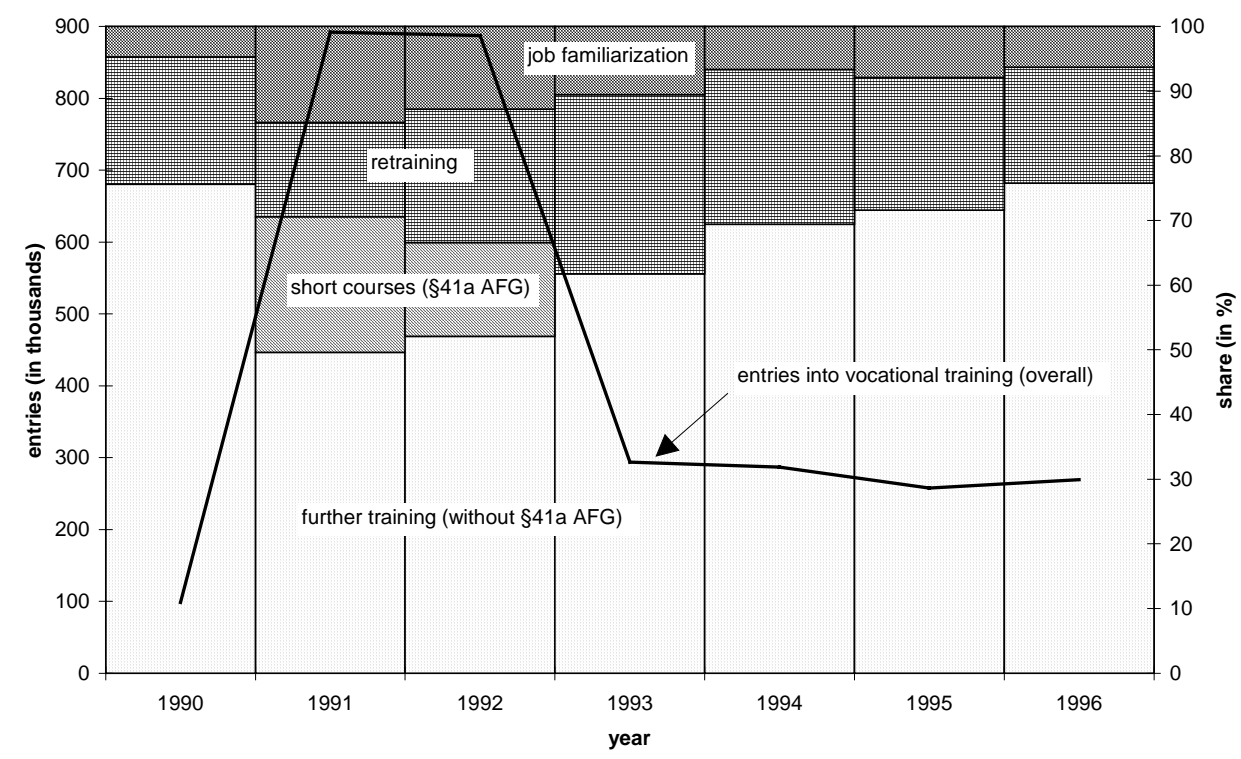

FIgURE 1.- Entries into different types of vocational training supported by the Federal Labor Office (East Germany, 1990-1996)

a) From 1993 onward short courses according to §41a AFG were canceled.

b) Note, the year 1990 only covers the months September to October. Moreover the numbers for further training in 1990 include short courses according to $§ 41 \mathrm{a}$ AFG since separate numbers were unavailable.

Source: Bundesanstalt für Arbeit: Förderung der beruflichen

Weiterbildung/Berufliche Weiterbildung various issues.

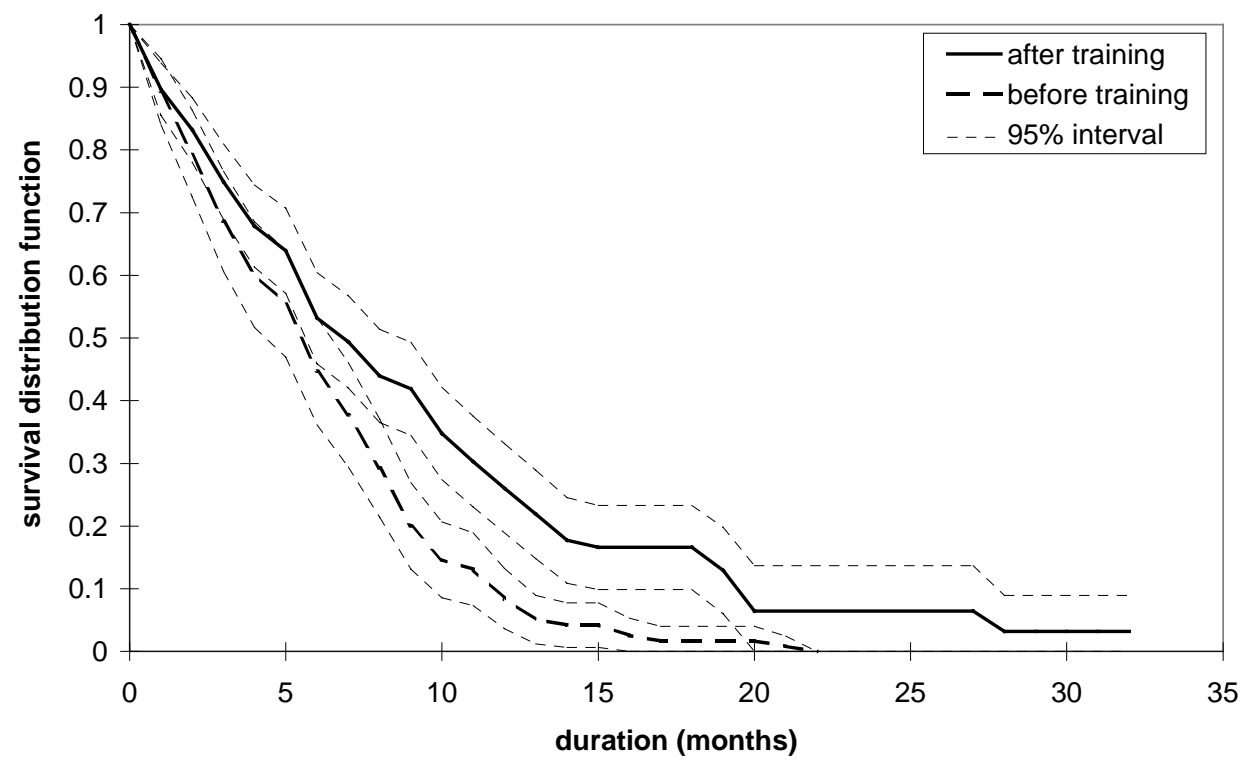

FIgURE 2.- Product limit estimates of the survivor function of trainees' unemployment spells before and after a FRMA measure 


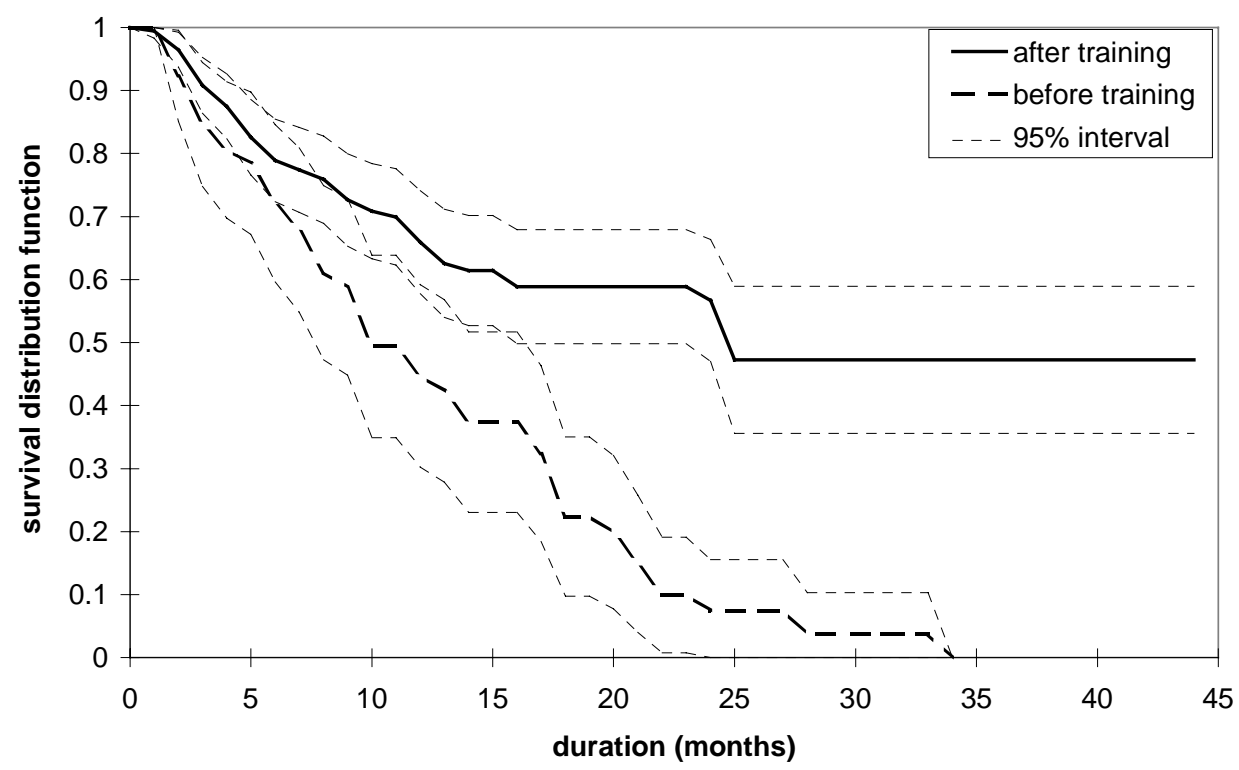

Figure 3.- Product limit estimates of the survivor function of trainees' employment spells before and after a FRMA measure

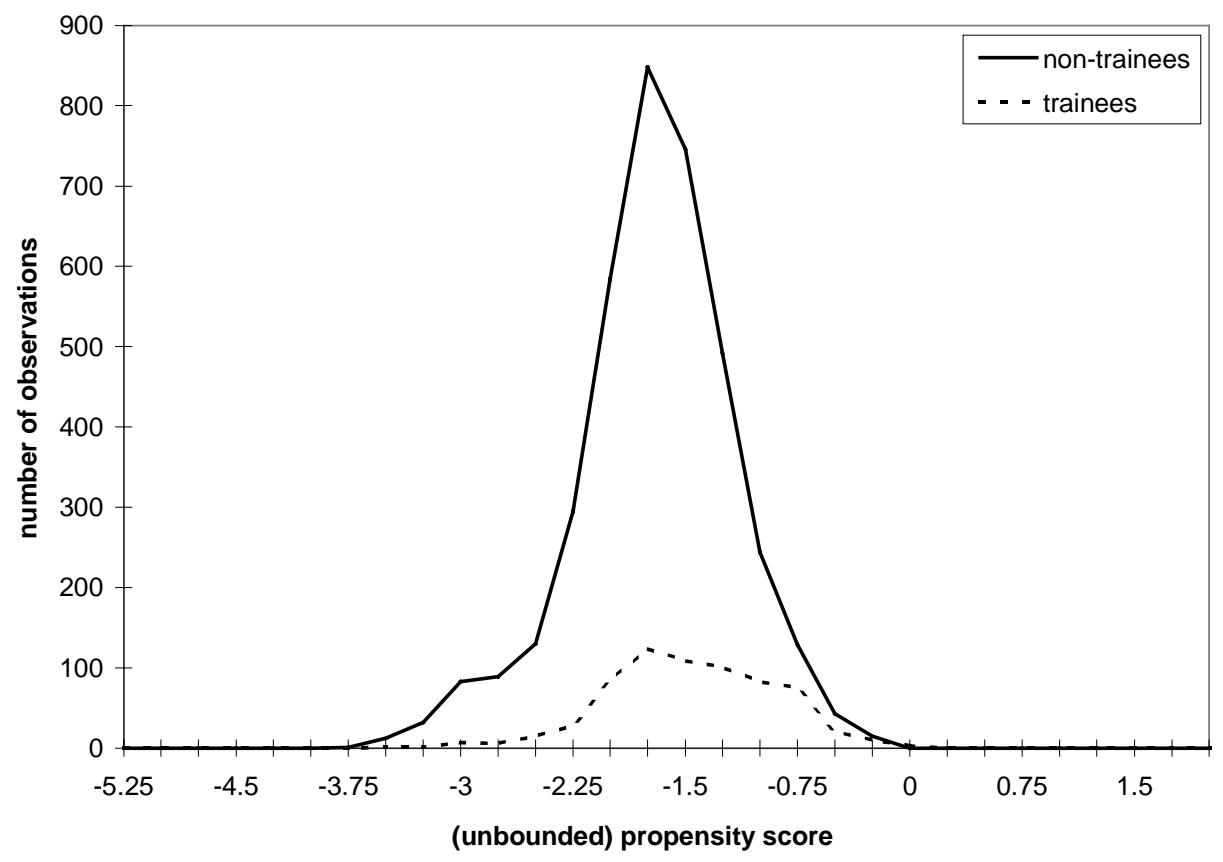

FiguRE 4.- Distribution of the propensity scores for the trainee and non-trainee groups (pooled for the years 1990-1992) 
TABLE 1

MEANS AND SHARES FOR SELECTED SOCIO-ECONOMIC CHARACTERISTICS FOR TRAINEES VS. NON-TRAINEES IN 1991 ${ }^{a}$ )

\begin{tabular}{lcc}
\hline \hline & Non-trainees & Trainees \\
Number of individuals & 1235 & 223 \\
\hline Age (years) & 31.6 & 32.4 \\
Male (\%) & 43 & 32 \\
High school degree (\%) & 13 & 18 \\
Apprenticeship (\%) & 66 & 68 \\
University degree (\%) & 19 & 28 \\
\hline \hline
\end{tabular}

a) Trainees (non-trainees) are those individuals who are observed in 1991 and who participated in a FRMA measure at least once (did not participate in a FRMA measure) during the time span under consideration 
TABLE 2

GMM ESTIMATES FOR PARTICIPATION IN PUBLIC VOCATIONAL TRAINING IN EASt GERmany (UNBALANCED PANEL PROBIt, 1990-1993)

\begin{tabular}{|c|c|c|}
\hline Variable & Coefficient & Standard error \\
\hline Intercept & -2.40870 & 0.61871 \\
\hline Age/10 & 0.14501 & 0.28703 \\
\hline$(\text { Age } / 10)^{2}$ & -0.03343 & 0.04106 \\
\hline Female & 0.30352 & 0.07489 \\
\hline Female $\times$ Kids & -0.08943 & 0.07762 \\
\hline PartHH & -0.06762 & 0.07990 \\
\hline Abitur & 0.15467 & 0.09200 \\
\hline Lehre & 0.30129 & 0.10608 \\
\hline Diplom & 0.42200 & 0.12704 \\
\hline SatisLife & -0.06214 & 0.01418 \\
\hline FutEmpDes & -0.20847 & 0.20779 \\
\hline Unemployed & 0.83307 & 0.11532 \\
\hline Employed & 0.14309 & 0.25918 \\
\hline WhiCollar & 0.18157 & 0.14107 \\
\hline BlueCollar & 0.10503 & 0.14571 \\
\hline JobEduc & -0.03293 & 0.08264 \\
\hline $\mathrm{Unm} \rightarrow \mathrm{Emp}$ & -0.24650 & 0.13496 \\
\hline $\mathrm{OLF} \rightarrow \operatorname{Emp}$ & -0.09075 & 0.12951 \\
\hline $\mathrm{Emp} \rightarrow \mathrm{Unm}$ & 0.21636 & 0.11789 \\
\hline $\mathrm{Unm} \rightarrow \mathrm{Unm}$ & -0.06938 & 0.19635 \\
\hline $\mathrm{OLF} \rightarrow \mathrm{Unm}$ & 0.11409 & 0.20349 \\
\hline $\mathrm{Emp} \rightarrow \mathrm{OLF}$ & 0.38029 & 0.18827 \\
\hline $\mathrm{Unm} \rightarrow \mathrm{OLF}$ & -0.72129 & 0.94327 \\
\hline $\mathrm{OLF} \rightarrow \mathrm{OLF}$ & -0.62763 & 0.71194 \\
\hline RegSituation & 0.00812 & 0.00303 \\
\hline Year90 & -0.16008 & 0.10678 \\
\hline Year91 & 0.25480 & 0.09073 \\
\hline Wald tests of joint restrictions & $\chi^{2}$ & p-val. \\
\hline $\begin{array}{l}\mathrm{H}_{0}: \text { coefficients of the year } \\
\text { dummies }=0\left(\chi^{2}(1)\right)\end{array}$ & 23.702 & 0.000 \\
\hline $\begin{array}{l}\mathrm{H}_{0}: \text { coefficients of labor force } \\
\text { status pattern }=0\left(\chi^{2}(7)\right)\end{array}$ & 17.444 & 1.475 \\
\hline $\mathrm{H}_{0}:$ all slope coefficients $=0\left(\chi^{2}(25)\right)$ & 223.042 & 0.000 \\
\hline McKelvey-Zavoina $\mathrm{R}^{2}$ & \multicolumn{2}{|c|}{0.222} \\
\hline Cross-validated $\mathrm{k}$ & \multicolumn{2}{|r|}{1137} \\
\hline Number of individuals & \multicolumn{2}{|r|}{1632} \\
\hline
\end{tabular}


TABLE 3

MAXIMUM LIKELIHOOD ESTIMATION OF A DISCRETE HAZARD RATE MODEL WITH UNOBSERVED HETEROGENEITY BASED ON A MATCHED SAMPLE (1990-1994)

Training effects on the transition unemployment $\Rightarrow$ employment

\begin{tabular}{|c|c|c|c|c|}
\hline \multirow{2}{*}{$\begin{array}{c}\text { Coefficient } \\
\text { (Standard error) }\end{array}$} & & \multicolumn{3}{|c|}{ Duration of the training course } \\
\hline & & $\begin{array}{l}\text { Short course } \\
\left(\mathrm{TR} \_ \text {Dur } 1-3\right)\end{array}$ & $\begin{array}{l}\text { Medium course } \\
\text { (TR_Dur4-6) }\end{array}$ & $\begin{array}{l}\text { Long course } \\
\left(\mathrm{TR} \_ \text {Dur7+) }\right.\end{array}$ \\
\hline & $\begin{array}{l}\text { marginal } \\
\text { effects }\end{array}$ & $\begin{array}{l}\text { reference } \\
\text { category }\end{array}$ & $\begin{array}{l}-0.4003 \\
(0.3385)\end{array}$ & $\begin{array}{l}-0.5867^{*} \\
(0.3318)\end{array}$ \\
\hline $\begin{array}{l}\text { The unemployment spells begins } \\
\text { - in the first month after } \\
\text { training ends (TR_1) }\end{array}$ & $\begin{array}{l}\text { reference } \\
\text { category }\end{array}$ & $\begin{array}{c}0.2177 \\
(0.3375)\end{array}$ & $\begin{array}{l}-0.1826 \\
(0.2956)\end{array}$ & $\begin{array}{l}-0.3690 \\
(0.2281)\end{array}$ \\
\hline $\begin{array}{l}\text { - within month } 2 \text { to } 12 \text { after } \\
\text { training ends (TR_2-12) }\end{array}$ & $\begin{array}{c}0.2299 \\
(0.2936)\end{array}$ & $\begin{array}{c}0.4476 \\
(0.3465)\end{array}$ & $\begin{array}{c}0.0473 \\
(0.3717)\end{array}$ & $\begin{array}{l}-0.1391 \\
(0.2922)\end{array}$ \\
\hline $\begin{array}{l}\text { - no earlier than } 1 \text { years } \\
\text { after training ends } \\
\text { (TR_13+) }\end{array}$ & $\begin{array}{l}-0.0792 \\
(0.2894)\end{array}$ & $\begin{array}{c}0.1385 \\
(0.3398)\end{array}$ & $\begin{array}{l}-0.2618 \\
(0.2833)\end{array}$ & $\begin{array}{l}-0.4482 \\
(0.3040)\end{array}$ \\
\hline
\end{tabular}

Training effects on the transition employment $\Rightarrow$ unemployment

\begin{tabular}{|c|c|c|c|c|}
\hline \multirow{2}{*}{$\begin{array}{c}\text { Coefficient } \\
\text { (Standard error) }\end{array}$} & & \multicolumn{3}{|c|}{ Duration of the training course } \\
\hline & & $\begin{array}{l}\text { Short course } \\
\text { (TR_Dur1-3) }\end{array}$ & $\begin{array}{l}\text { Medium course } \\
\text { (TR_Dur4-6) }\end{array}$ & $\begin{array}{l}\text { Long course } \\
\text { (TR_Dur7+) }\end{array}$ \\
\hline & $\begin{array}{c}\text { marginal } \\
\text { effects }\end{array}$ & $\begin{array}{l}\text { reference } \\
\text { category }\end{array}$ & $\begin{array}{c}0.2504 \\
(0.4647)\end{array}$ & $\begin{array}{c}0.0578 \\
(0.4560)\end{array}$ \\
\hline \multicolumn{5}{|l|}{ The employment spells begins } \\
\hline $\begin{array}{l}\text { - in the first months after } \\
\text { training ends (TR_1) }\end{array}$ & $\begin{array}{l}\text { reference } \\
\text { category }\end{array}$ & $\begin{array}{c}0.7709 \\
(0.8154)\end{array}$ & $\begin{array}{c}1.0213 \\
(0.8977)\end{array}$ & $\begin{array}{c}0.8287 \\
(0.8346)\end{array}$ \\
\hline $\begin{array}{l}\text { - within month } 2 \text { to } 12 \text { after } \\
\text { training ends (TR_2-12) }\end{array}$ & $\begin{array}{l}-0.8305 \\
(0.8105)\end{array}$ & $\begin{array}{l}-0.0596 \\
(0.4157)\end{array}$ & $\begin{array}{c}0.1908 \\
(0.4077)\end{array}$ & $\begin{array}{l}-0.0018 \\
(0.3112)\end{array}$ \\
\hline $\begin{array}{l}\text { - no earlier than } 1 \text { years } \\
\text { after training ends } \\
\text { (TR_13+) }\end{array}$ & $\begin{array}{l}-0.8030 \\
(0.8439)\end{array}$ & $\begin{array}{l}-0.0321 \\
(0.4330)\end{array}$ & $\begin{array}{c}0.2183 \\
(0.4494)\end{array}$ & $\begin{array}{l}-0.0257 \\
(0.4549)\end{array}$ \\
\hline
\end{tabular}

* denotes significance at a 10\% level. 


\section{APPENDIX}

TABle A.1

DEFINITION OF VARIABLES

\begin{tabular}{|c|c|}
\hline Variable & Description \\
\hline \multicolumn{2}{|c|}{ Training variables } \\
\hline TR & 1 if the individual participated in a training course. \\
\hline TR_2-12 & $\begin{array}{l}1 \text { if the training course ended earlier than one month and no later than } \\
\text { twelve months prior to the unemployment spell begin. }\end{array}$ \\
\hline TR_13+ & $\begin{array}{l}1 \text { if the training course ended later than twelve months prior to the } \\
\text { unemployment spell begin. }\end{array}$ \\
\hline \multicolumn{2}{|c|}{$\begin{array}{l}\text { - reference category: if the training course ended in the month prior to the } \\
\text { unemployment spell begin. }\end{array}$} \\
\hline TR_Dur4-6 & $\begin{array}{l}1 \text { if the PSVT course lasted longer than three but no longer than six } \\
\text { months. }\end{array}$ \\
\hline \multicolumn{2}{|c|}{$\begin{array}{l}\text { TR_Dur7+ } \quad 1 \text { if the training course lasted longer than six months. } \\
\text { - reference category: if the training course lasted no longer than three months. }\end{array}$} \\
\hline \multicolumn{2}{|c|}{ Baseline dummy variables - reference category is first month of spell duration } \\
\hline Basexx & 1 if current month is month $\mathrm{xx}$ since spell begin. \\
\hline & 1 if current month is one of the mont \\
\hline Basexx+ + & 1 if current month is month $\mathrm{xx}$ or hig \\
\hline \multicolumn{2}{|c|}{ Seasonal variables } \\
\hline Spring & 1 if current mont \\
\hline Summer & 1 if cur \\
\hline December & 1 if curre \\
\hline Yearxx & 1 if date of interview is in year $x x$ \\
\hline \multicolumn{2}{|c|}{ Macroeconomic and regional labor market indicator } \\
\hline RegSituation & $\begin{array}{l}\text { Defined as the quotient between the number of unemployed and vacancie } \\
\text { in the state in which the individual has his place of residence. }\end{array}$ \\
\hline \multicolumn{2}{|l|}{ Age variables } \\
\hline $\begin{array}{l}\text { Age/10 } \\
(\text { Age/10 }\end{array}$ & $\begin{array}{l}\text { Age divided by } 10 \text {. } \\
\text { Age squared and divided by } 100 \text {. }\end{array}$ \\
\hline \multicolumn{2}{|c|}{ Age dummy variables - reference category is 41 years or older. } \\
\hline Age $-25 y r s$ & 1 if individual is 25 years or younger. \\
\hline Age $26-40 \mathrm{yrs}$ & 1 if individual is $26 \mathrm{y}$ \\
\hline \multicolumn{2}{|c|}{ Other socio-demographic variables } \\
\hline Female & 1 if individual is female. \\
\hline Female $\times$ Kids & 1 if individual is female and has children aged up to 15 . \\
\hline PartHH & 1 if individual is married or living together with his/her partner. \\
\hline Abitur & $\begin{array}{l}1 \text { if individual has Abitur or Fachhochschulreife (comp. to high school } \\
\text { degree). }\end{array}$ \\
\hline Lehre & 1 if individual has completed an apprenticeship. \\
\hline Diplom & 1 if individual has a university degree or a degree from a Fachhochschule. \\
\hline SatisLife & $\begin{array}{l}\text { Satisfaction with life in general ( } 0=\text { totally dissatisfied; } 10=\text { totally } \\
\text { satisfied). }\end{array}$ \\
\hline
\end{tabular}


Definition of VARiables (CONTINUEd)

\begin{tabular}{lrl}
\hline \hline \multicolumn{1}{c}{ Variable } & \multicolumn{1}{c}{ Description } \\
\hline Variables related to current employment status \\
\hline Unemployed & 1 if individual is currently unemployed. \\
Employed & 1 if individual is currently employed. \\
Occupational Status - reference category are apprentices and self-employed. \\
WhiCollar & 1 if individual is currently employed and has white collar status. \\
BlueCollar & 1 if individual is currently employed and has blue collar status. \\
FirmSize & 1 if the firm has less than 20 employees or the individual is self-employed. \\
& 2 if the firm has 20 or more, but less than 200 employees. \\
& 3 if the firm has 200 or more, but less than 2000 employees. \\
JobEduc & 4 if the firm has 2000 or more employees. \\
& 1 if individual is working in the occupation he/she was originally \\
PublicSector & 1 if individual is currently employed in the public sector
\end{tabular}

Variables related to the labor force status pattern:

They are defined by looking backward in time starting in the month in which the interview took place and ending eleven months earlier. The first status is the most recent prior status within the indicated time period. Thus Emp $\rightarrow$ Unm refers to an individual who was unemployed at the month of the interview but whose most recent labor force status during the preceding eleven month was employment. Repeated pattern such as Unm $\rightarrow$ Unm indicate that the individual had the same labor force status in the month of the interview and in all of the elven preceding months. The reference category is Emp $\rightarrow$ Emp (if individual remained employed for all twelve month).

\begin{tabular}{lll}
\hline Unm $\rightarrow$ Emp & 1 if individual switched from unemployment to employment. \\
OLF $\rightarrow$ Emp & 1 if individual switched from out of the labor force to employment. \\
Emp $\rightarrow$ Unm & 1 if individual switched from employment to unemployment. \\
Unm $\rightarrow$ Unm & 1 if individual remained unemployed for all twelve months. \\
OLF $\rightarrow$ Unm & 1 if individual switched from out of the labor force to unemployment. \\
Emp $\rightarrow$ OLF & 1 if individual switched from employment to out of the labor force. \\
Unm $\rightarrow$ OLF & 1 if individual switched from unemployment to out of the labor force. \\
OLF $\rightarrow$ OLF & 1 if individual remained out of the labor force for all twelve months.
\end{tabular}

Variables related to future plans regarding employment

\begin{tabular}{|c|c|}
\hline FutPartTime & $\begin{array}{l}1 \text { if individual is currently not employed but wishes to be employed in } \\
\text { the future. } \\
1 \text { if individual is currently not employed but wishes to be employed in } \\
\text { the future and is looking for a part time employment. }\end{array}$ \\
\hline \multicolumn{2}{|c|}{ Variables related to employment history } \\
\hline NoUneSp1 & $\begin{array}{l}\text { number of unemployment spells during the last year (measured from } \\
\text { spell begin) }\end{array}$ \\
\hline DurUneSp1 & $\begin{array}{l}\text { cumulated number of unemployment months during the last year } \\
\text { (measured from spell begin and divided by } 12 \text { ). }\end{array}$ \\
\hline PrvEmployed & $\begin{array}{l}1 \text { if individual was previously, i.e. prior to the unemployment spell, } \\
\text { employed. }\end{array}$ \\
\hline PrvUnemployed & $\begin{array}{l}1 \text { if individual was previously, i.e. prior to the employment spell, } \\
\text { unemployed. }\end{array}$ \\
\hline ReplacementRatio & $\begin{array}{l}\text { Level of unemployment benefits in relation to the last labor market } \\
\text { gross income. }\end{array}$ \\
\hline
\end{tabular}


TABLE A.2

NeARest aVAilable MAhalanobis Metric MATChing Within CALIPERS DEFINED BY THE ESTIMATED PROPENSITY SCORE

Step 1 Divide the individuals into two separate groups called trainees and non-trainees according to whether they have participated in public vocational training during the given time $\operatorname{span}^{a)}$ (trainee group) or not (non-trainee group).

Step 2 Randomly select a trainee (denoted by i) from the trainee group. If this trainee participated in more than one public vocational training course take the earliest one as being relevant for the following steps.

Step 3 Based on the estimated unbalanced panel probit model compute the (unbounded) propensity score $\mathrm{z}_{\mathrm{i}}^{\prime} \hat{\beta}$ and its variance $\operatorname{Var}\left(\mathrm{z}_{\mathrm{i}}^{\prime} \beta\right)$ for the trainee $i$ in wave $t$, where $t$ refers to the date of the interview prior to the beginning of the public vocational course. Construct the interval (caliper) $\mathrm{z}_{\mathrm{it}}^{\prime} \hat{\beta} \pm \mathrm{c} \sqrt{\operatorname{Var}\left(\mathrm{z}_{\mathrm{it}}^{\prime} \hat{\beta}\right)}$ for this trainee, and choose $c$ such that one obtains a 90\%-confidence interval around $z_{i t}^{\prime} \hat{\beta}$.

Step 4 Find observations in the non-trainee group (denoted by $j$ ), that obey $\mathrm{z}_{\mathrm{jt}}^{\prime} \hat{\beta} \in\left(\mathrm{z}_{\mathrm{it}}^{\prime} \hat{\beta} \pm \mathrm{c} \sqrt{\operatorname{Var}\left(\mathrm{z}_{\mathrm{it}}^{\prime} \hat{\beta}\right)}\right)$ in wave t.

Step 5 (a) If there is no non-trainee lying between the given limits of the confidence interval, trainee $i$ will not be considered further and step 2 has to be repeated.

(b) If there are one or more observations in the confidence interval proceed as follows: Compute additional match variables related to monthly pre-training employment status and a subset of variables already included in the estimation of the propensity score. Denote these variables as $\mathrm{a}_{\mathrm{it}}$ and $\mathrm{a}_{\mathrm{jt}}$. Evaluate the distance $\mathrm{d}(\mathrm{j}, \mathrm{i})=\left(\mathrm{z}_{\mathrm{jt}}^{\prime} \hat{\beta}, \mathrm{a}_{\mathrm{jt}}\right)^{\prime}-\left(\mathrm{z}_{\mathrm{it}}^{\prime} \hat{\beta}, \mathrm{a}_{\mathrm{it}}\right)^{\prime}$ between each non-trainee $\mathrm{j}$ and trainee i. Choose the non-trainee who is the "closest neighbor" of the trainee $i$ in terms of the Mahalanobis distance, defined as: $\operatorname{md}(\mathrm{j}, \mathrm{i})=\mathrm{d}(\mathrm{j}, \mathrm{i})^{\prime} \mathrm{L}^{-1} \mathrm{~d}(\mathrm{j}, \mathrm{i})$, where $L$ is the estimated sample covariance matrix of $\left(\mathrm{z}^{\prime} \hat{\beta}, \mathrm{a}\right)^{\prime}$ in the group of non-trainees in wave $t$.

Step 6 Remove the trainee and non-trainee (now matched control) from their respective groups. If there are any observations left in the trainee group, start again with step 2.

a) The relevant time span refers to 1990 to early 1993 
TABLE A.3

TRAINEES VERSUS MATCHED NON-TRAINEES FOR SELECTED CHARACTERISTICS; MATCHING IS CONDITIONED ON A POST-TRAINING UNEMPLOYMENT SPELL

\begin{tabular}{|c|c|c|c|c|c|c|c|}
\hline & \multirow{2}{*}{$\begin{array}{c}\text { trainees } \\
(142) \\
\end{array}$} & \multicolumn{5}{|c|}{ matched non-trainees } & \multirow{2}{*}{$\begin{array}{c}\text { all non-trainees } \\
(1401)\end{array}$} \\
\hline & & $\begin{array}{c}\text { OTOS } \\
(142)\end{array}$ & $\begin{array}{l}\text { OVS1 } \\
(272) \\
\end{array}$ & $\begin{array}{c}\text { OVS2 } \\
(378)\end{array}$ & $\begin{array}{c}\text { OVS3 } \\
(467)\end{array}$ & $\begin{array}{c}\text { OVS4 } \\
(540)\end{array}$ & \\
\hline Variable & $\begin{array}{l}\text { mean, } \\
\text { share } \\
\text { in } \%\end{array}$ & $\begin{array}{l}\text { mean, } \\
\text { share } \\
\text { in } \%\end{array}$ & $\begin{array}{l}\text { mean, } \\
\text { share } \\
\text { in } \%\end{array}$ & $\begin{array}{l}\text { mean, } \\
\text { share } \\
\text { in } \%\end{array}$ & $\begin{array}{l}\text { mean, } \\
\text { share } \\
\text { in } \%\end{array}$ & $\begin{array}{l}\text { mean, } \\
\text { share } \\
\text { in } \%\end{array}$ & $\begin{array}{c}\text { mean, } \\
\text { share } \\
\text { in } \%\end{array}$ \\
\hline \multicolumn{8}{|c|}{ Characteristics referring to the date of interview prior to training } \\
\hline$z^{\prime} \hat{\beta}$ & -1.37 & -1.38 & -1.42 & $-1.48 * *$ & $-1.52 * *$ & $-1.56^{* *}$ & $-1.92 * *$ \\
\hline Female & 69.7 & 62.0 & 64.7 & 64.0 & 62.5 & $60.7 * *$ & $56.7 * *$ \\
\hline Age & 32.8 & 34.1 & $34.6^{*}$ & $34.5^{* *}$ & $34.2 *$ & 34.0 & $30.6 * *$ \\
\hline PartHH & 81.1 & 78.2 & 83.5 & 83.9 & 82.9 & 82.6 & $72.5 * *$ \\
\hline Diplom & 26.3 & $15.0 * *$ & $17.8^{*}$ & $18.1^{*}$ & $16.4 * *$ & $15.1 * *$ & $17.8 * *$ \\
\hline SatisLife & 5.3 & 5.1 & 5.3 & 5.5 & 5.5 & 5.6 & $6.3 * *$ \\
\hline FutEmpDes & 41.7 & 43.9 & 35.0 & $29.2 * *$ & $27.0 * *$ & $23.9 * *$ & $29.3 * *$ \\
\hline BlueCollar & 21.1 & 26.8 & $30.5^{*} *$ & $32.3^{* *}$ & $33.0 * *$ & $36.3 * *$ & $30.1 * *$ \\
\hline \multicolumn{8}{|c|}{ Unemployment rate at selected months prior to training } \\
\hline month 1 & 62.0 & 57.1 & $43.9 * *$ & $35.4 * *$ & $30.0 * *$ & $26.0 * *$ & $14.2 * *$ \\
\hline month 1 to 4 (average) & 54.1 & 51.8 & $39.6 * *$ & $31.9 * *$ & $27.2 * *$ & $23.7 * *$ & $12.7 * *$ \\
\hline months 1 to 12 (average) & 36.4 & 34.2 & $25.9 * *$ & $20.7^{* *}$ & $17.6 * *$ & $15.3 * *$ & $9.9 * *$ \\
\hline $\operatorname{median}(\mathrm{sd})$ & - & 6.5 & 28.1 & 44.4 & 53.7 & 61.8 & 84.7 \\
\hline $\operatorname{mean}(\mathrm{sd})$ & - & 9.5 & 25.3 & 38.4 & 47.4 & 55.0 & 73.1 \\
\hline
\end{tabular}

${ }^{* *}\left({ }^{*}\right)$ denotes significance at a $5 \%(10 \%)$ level. 
TABLE A.4

TRAINEES VERSUS MATCHED NON-TRAINEES FOR SELECTED CHARACTERISTICS; MATCHING IS CONDITIONED ON A POST-TRAINING

EMPLOYMENT SPELL

\begin{tabular}{|c|c|c|c|c|c|c|c|}
\hline & \multirow{2}{*}{$\begin{array}{c}\text { trainees } \\
(123) \\
\end{array}$} & \multicolumn{5}{|c|}{ matched non-trainees } & \multirow{2}{*}{$\begin{array}{c}\text { all non-trainees } \\
(1401) \\
\end{array}$} \\
\hline & & $\begin{array}{l}\text { OTOS } \\
(123)\end{array}$ & $\begin{array}{l}\text { OVS1 } \\
(242) \\
\end{array}$ & $\begin{array}{l}\text { OVS2 } \\
(358) \\
\end{array}$ & $\begin{array}{l}\text { OVS3 } \\
(462)\end{array}$ & $\begin{array}{l}\text { OVS4 } \\
(550)\end{array}$ & \\
\hline Variable & $\begin{array}{c}\text { mean, } \\
\text { share } \\
\text { in } \%\end{array}$ & $\begin{array}{l}\text { mean, } \\
\text { share } \\
\text { in } \%\end{array}$ & $\begin{array}{l}\text { mean, } \\
\text { share } \\
\text { in } \%\end{array}$ & $\begin{array}{l}\text { mean, } \\
\text { share } \\
\text { in } \%\end{array}$ & $\begin{array}{l}\text { mean, } \\
\text { share } \\
\text { in } \%\end{array}$ & $\begin{array}{l}\text { mean, } \\
\text { share } \\
\text { in } \%\end{array}$ & $\begin{array}{c}\text { mean, } \\
\text { share } \\
\text { in } \%\end{array}$ \\
\hline \multicolumn{8}{|c|}{ Characteristics referring to the date of interview prior to training } \\
\hline$z \hat{\beta}$ & -1.43 & -1.44 & -1.46 & -1.47 & -1.50 & $-1.53 * *$ & $-1.92 * *$ \\
\hline Female & 65.0 & 63.4 & 62.8 & 61.7 & 61.7 & 60.7 & $56.7 *$ \\
\hline Age & 32.8 & 34.0 & 34.3 & 33.5 & 33.4 & 32.9 & $30.6^{* *}$ \\
\hline PartHH & 82.1 & 77.9 & 79.7 & 81.2 & 80.5 & 79.6 & $72.5^{* *}$ \\
\hline Diplom & 30.4 & $20.6^{*}$ & $18.3^{* * *}$ & $19.4^{*}$ & $17.9 * *$ & $16.9 * *$ & $17.8^{* *}$ \\
\hline SatisLife & 5.4 & 5.6 & 5.6 & 5.7 & 5.7 & $5.7 *$ & $6.3^{* *}$ \\
\hline FutEmpDes & 38.2 & 40.0 & 42.1 & 38.2 & 34.6 & 31.3 & $29.3 *$ \\
\hline BlueCollar & 20.3 & $30.1 *$ & $29.8^{* *}$ & $31.3 * *$ & $33.1 * *$ & $34.9 * *$ & $30.1 * *$ \\
\hline \multicolumn{8}{|c|}{ Unemployment rate at selected months prior to training } \\
\hline month 1 & 60.2 & 59.4 & 55.6 & $49.7 * *$ & $44.0 * *$ & $39.4 * *$ & $14.2 * *$ \\
\hline month 1 to 4 (average) & 51.8 & 51.5 & 48.9 & $43.5^{*}$ & $38.2 * *$ & $33.8 * *$ & $12.7 * *$ \\
\hline months 1 to 12 (average) & 32.8 & 33.0 & 31.4 & 27.7 & $24.1 * *$ & $21.1 * *$ & $9.9 * *$ \\
\hline median $(\mathrm{sd})$ & - & 2.4 & 6.5 & 18.2 & 29.0 & 34.0 & 78.0 \\
\hline mean(sd) & - & 4.7 & 8.9 & 17.4 & 26.6 & 34.1 & 73.8 \\
\hline
\end{tabular}

${ }^{* *}\left({ }^{*}\right)$ denotes significance at a $5 \%(10 \%)$ level. 
TABLE A.5

RESULTS FOR TRANSITION UNEMPLOYMENT $\rightarrow$ EMPLOYMENT: MAXIMUM LIKELIHOOD ESTIMATION OF A DISCRETE HAZARD RATE MODEL WITH UNOBSERVED HETEROGENEITY BASED ON A MATCHED SAMPLE

(1990-1994)

\begin{tabular}{lrc}
\hline \hline Variable & Coefficient & Standard error \\
\hline Constant & -4.0061 & 0.6335 \\
Base02 & -0.0070 & 0.6335 \\
Base0304 & -0.0867 & 0.2657 \\
Base0506 & 0.2671 & 0.2493 \\
Base0709 & 0.2642 & 0.2787 \\
Base10+ & 0.7720 & 0.3283 \\
Age -25yrs & 0.3282 & 0.2569 \\
Age 26-40yrs & 0.0231 & 0.2299 \\
Female & -0.4380 & 0.2504 \\
FemalexKids & 0.1358 & 0.2476 \\
PartHH & 0.1205 & 0.2413 \\
Abitur & 0.1158 & 0.3199 \\
Lehre & 0.4773 & 0.2965 \\
Diplom & 0.8011 & 0.3549 \\
PrvEmployed & 1.3330 & 0.3755 \\
NoUneSp1 & 0.1254 & 0.2472 \\
DurUneSp1 & -0.1398 & 0.1720 \\
ReplacementRatio & -0.4443 & 0.1422 \\
RegSituation & 0.0074 & 0.0130 \\
December & 0.1927 & 0.2574 \\
Spring & 0.3226 & 0.1692 \\
Summer & -0.1679 & 0.2189 \\
TR & 0.2177 & 0.3375 \\
TR_Dur4-6 & -0.4003 & 0.3385 \\
TR_Dur7+ & -0.5867 & 0.3318 \\
TR_2-12 & 0.2299 & 0.2936 \\
TR_13+ & -0.0792 & 0.2894 \\
Ln $\left(\sigma^{2}\right)$ & -1.4257 & 1.0020 \\
\hline Likelihood Ratio test & $\chi^{2}$ & $\mathrm{p}$-val. \\
of joint restrictions & & \\
Ho: all coefficients except intercept & 62.3976 & 0.000 \\
and base line $=0\left(\chi^{2}(22)\right)$ & & \\
\hline Log-Likelihood & -725.9337 \\
Number of spells & & 355 \\
\hline \hline & & \\
\hline
\end{tabular}


TABLE A.6

RESULTS FOR TRANSITION EMPLOYMENT $\rightarrow$ UNEMPLOYMENT: MAXIMUM

LIKELIHOOD ESTIMATION OF A DISCRETE HAZARD RATE MODEL WITH

UNOBSERVED HETEROGENEITY BASED ON A MATCHED SAMPLE

(1990-1994)

\begin{tabular}{|c|c|c|}
\hline Variable & Coefficient & Standard error \\
\hline Constant & -6.8052 & 1.5630 \\
\hline Base0304 & 1.0498 & 0.3836 \\
\hline Base0506 & 1.1852 & 0.4115 \\
\hline Base0709 & 1.5329 & 0.4355 \\
\hline Base1012 & 1.2983 & 0.5377 \\
\hline Base1315 & 1.7233 & 0.5940 \\
\hline Base16+ & 0.4272 & 0.7414 \\
\hline Age -25yrs & 1.1338 & 0.3823 \\
\hline Age $26-40 y r s$ & 0.3638 & 0.2855 \\
\hline Female & -0.0067 & 0.3262 \\
\hline Female $\times$ Kids & -0.0115 & 0.3257 \\
\hline PartHH & 0.0171 & 0.2956 \\
\hline Abitur & 0.0432 & 0.4148 \\
\hline Lehre & -0.1943 & 0.3576 \\
\hline Diplom & -0.3274 & 0.5106 \\
\hline PrvUnemployed & 2.6401 & 1.1431 \\
\hline SatisLife & -0.2197 & 0.0579 \\
\hline FirmSize & 0.0255 & 0.1341 \\
\hline PublicSector & 0.2779 & 0.2382 \\
\hline WhiCollar & 0.3814 & 0.4674 \\
\hline BlueCollar & 0.9209 & 0.4852 \\
\hline RegSituation & 0.0008 & 0.0168 \\
\hline December & 0.6466 & 0.3027 \\
\hline Spring & -0.4392 & 0.3183 \\
\hline Summer & -0.0676 & 0.2528 \\
\hline $\mathrm{TR}$ & 0.7709 & 0.8154 \\
\hline TR_Dur4-6 & 0.2504 & 0.4647 \\
\hline TR_Dur7+ & 0.0578 & 0.4560 \\
\hline TR_2-12 & -0.8305 & 0.8105 \\
\hline TR_13+ & -0.8030 & 0.8439 \\
\hline $\operatorname{Ln}\left(\sigma^{2}\right)$ & -0.6150 & 1.4347 \\
\hline $\begin{array}{l}\text { Likelihood Ratio test } \\
\text { of joint restrictions }\end{array}$ & $\chi^{2}$ & p-val. \\
\hline $\begin{array}{l}\mathrm{H}_{0}: \text { all coefficients except intercept } \\
\text { and base line }=0\left(\chi^{2}(24)\right)\end{array}$ & 76.3352 & 0.000 \\
\hline Log-Likelihood & \multicolumn{2}{|c|}{-559.8553} \\
\hline Number of spells & \multicolumn{2}{|c|}{450} \\
\hline
\end{tabular}




\section{IZA Discussion Papers}

\begin{tabular}{|c|c|c|c|c|}
\hline No. & Author(s) & Title & Area & Date \\
\hline 41 & $\begin{array}{l}\text { J. M. Orszag } \\
\text { D. J. Snower }\end{array}$ & Anatomy of Policy Complementarities & $3 / 7$ & $5 / 99$ \\
\hline 42 & D. S. Hamermesh & The Changing Distribution of Job Satisfaction & 7 & $5 / 99$ \\
\hline 43 & $\begin{array}{l}\text { C. Belzil } \\
\text { J. Hansen }\end{array}$ & $\begin{array}{l}\text { Household Characteristics, Ability and Education: } \\
\text { Evidence from a Dynamic Expected Utility Model }\end{array}$ & 7 & $5 / 99$ \\
\hline 44 & $\begin{array}{l}\text { D. N. F. Bell } \\
\text { R. A. Hart }\end{array}$ & $\begin{array}{l}\text { Overtime Working in an Unregulated Labour } \\
\text { Market }\end{array}$ & 1 & $6 / 99$ \\
\hline 45 & $\begin{array}{l}\text { R. A. Hart } \\
\text { J. R. Malley }\end{array}$ & On the Cyclicality and Stability of Real Earnings & 1 & $6 / 99$ \\
\hline 46 & $\begin{array}{l}\text { R. Rotte } \\
\text { M. Vogler }\end{array}$ & $\begin{array}{l}\text { The Effects of Development on Migration: } \\
\text { Theoretical Issues and New Empirical Evidence }\end{array}$ & 2 & $6 / 99$ \\
\hline 47 & $\begin{array}{l}\text { R. A. Hart } \\
\text { F. Ritchie }\end{array}$ & Tenure-based Wage Setting & $1 / 7$ & $7 / 99$ \\
\hline 48 & $\begin{array}{l}\text { T. Bauer } \\
\text { K. F. Zimmermann }\end{array}$ & $\begin{array}{l}\text { Overtime Work and Overtime Compensation in } \\
\text { Germany }\end{array}$ & 1 & $7 / 99$ \\
\hline 49 & H. P. Grüner & $\begin{array}{l}\text { Unemployment and Labor-Market Reform: A } \\
\text { Contract Theoretic Approach }\end{array}$ & $1 / 3$ & $7 / 99$ \\
\hline 50 & K. F. Zimmermann & $\begin{array}{l}\text { Ethnic German Migration After } 1989 \text { - Balance } \\
\text { and Perspectives }\end{array}$ & 1 & $8 / 99$ \\
\hline 51 & $\begin{array}{l}\text { A. Barrett } \\
\text { P. J. O'Connell }\end{array}$ & $\begin{array}{l}\text { Does Training Generally Work? } \\
\text { The Returns to In-Company Training }\end{array}$ & 7 & $8 / 99$ \\
\hline 52 & $\begin{array}{l}\text { J. Mayer } \\
\text { R. T. Riphahn }\end{array}$ & $\begin{array}{l}\text { Fertility Assimilation of Immigrants: Evidence } \\
\text { from Count Data Models }\end{array}$ & 3 & $8 / 99$ \\
\hline 53 & $\begin{array}{l}\text { J. Hartog } \\
\text { P. T. Pereira } \\
\text { J. A. C. Vieira }\end{array}$ & $\begin{array}{l}\text { Inter-industry Wage Dispersion in Portugal: high } \\
\text { but falling }\end{array}$ & 7 & $8 / 99$ \\
\hline 54 & M. Lofstrom & $\begin{array}{l}\text { Labor Market Assimilation and the } \\
\text { Self-Employment Decision of Immigrant } \\
\text { Entrepreneurs }\end{array}$ & 1 & $8 / 99$ \\
\hline 55 & L. Goerke & $\begin{array}{l}\text { Value-added Tax versus Social Security } \\
\text { Contributions }\end{array}$ & 3 & $8 / 99$ \\
\hline 56 & $\begin{array}{l}\text { A. Lindbeck } \\
\text { D. J. Snower }\end{array}$ & $\begin{array}{l}\text { Centralized Bargaining and Reorganized Work: } \\
\text { Are they compatible? }\end{array}$ & $1 / 5$ & $9 / 99$ \\
\hline 57 & $\begin{array}{l}\text { I. N. Gang } \\
\text { K. F. Zimmermann }\end{array}$ & $\begin{array}{l}\text { Is Child like Parent? } \\
\text { Educational Attainment and Ethnic Origin }\end{array}$ & 1 & $9 / 99$ \\
\hline
\end{tabular}


D. J. DeVoretz

S. A. Laryea

60

C. Belzil

J. Hansen

61

62

63

64

65

H. Lehmann

J. Wadsworth

A. Acquisti

66

E. J. Bird

H. Kayser

J. R. Frick

G. G. Wagner

67 R. T. Riphahn

A. Thalmaier

68

B. Dietz

69

M.-S. Yun

70

I. N. Gang

F.L. Rivera-Batiz

71 L. Goerke

72 J. Fersterer

R. Winter-Ebmer

73 G. S. Epstein

S. Nitzan

$74 \quad$ M. Kräkel

75 B. Henry

M. Karanassou

D. J. Snower

76 G. Brunello

M. Giannini

77 C. M. Schmidt
Occupational Mobility of Ethnic Migrants

Canadian Immigration Experience:

Any Lessons for Europe?

Subjective Discount Rates, Intergenerational

7

$10 / 99$

Transfers and the Return to Schooling

Immigration: The New Zealand Experience

7

$10 / 99$

Bestimmungsgründe von Fehlzeiten: Welche

3

$10 / 99$

Rolle spielt die Arbeitslosigkeit?

Your Everyday, Average Academic

$10 / 99$

Salary and the Gender Salary Gap in the Academic Profession

$10 / 99$

Grime and Punishment: Job Insecurity and Wage

$10 / 99$

Arrears in the Russian Federation

The Immigrant Welfare Effect: Take-Up or

Eligibility?

Behavioral Effects of Probation Periods:

An Analysis of Worker Absenteeism

Ethnic German Immigration from Eastern Europe and the former Soviet Union to Germany: the Effects of Migrant Networks

Generalized Selection Bias and the Decomposition 7 of Wage Differentials

Immigrants and Unemployment in the European 1

Community

The Wedge

Are Austrian Returns to Education Falling Over $\quad 7$

Time?

The Endogenous Determination of Minimum Wage 3

Adjustment Dynamics and the Natural Rate: An 1

Account of UK Unemployment

Selective Schools 
Entrepreneurship from Scratch: Lessons on the

80 J. C. van Ours J. Veenman

The Netherlands: Old Emigrants - Young Immigrant Country

Migration, Migrants and Policy in the United Kingdom
Privacy, time consistent optimal labor income taxation and education policy

Female Labour Supply, Flexibility of Working Hours, 1 and Job Mobility in the Netherlands

The Heterogeneity and Cyclical Sensitivity of 1 Unemployment: An Exploration of German Labor Market Flows

Gender and Racial Discrimination in Pay and 5/6 Promotion for NHS Nurses

Money for Nothing and Your Chips for Free?

The Anatomy of the PC Wage Differential

Educational Mismatch and Wages in Germany $\quad 7$

Migration in Spain: Historical Background and 1 Current Trends

Aliyah to Israel: Immigration under Conditions of 1 Adversity

Tenures that Shook the World: Worker Turnover in 4 Russia, Poland and Britain

Identification and Estimation of Causal Effects of Multiple Treatments Under the Conditional Independence Assumption

The Rate of Return to Private Schooling

An Evaluation of Public-Sector-Sponsored 6 Continuous Vocational Training Programs in East Germany

An Evaluation of Public Employment Programmes 6 in the East German State of Sachsen-Anhalt Job Protection, Minimum Wage and Unemployment 3 
N. Smith

102 B. van der Klaauw J. C. van Ours

B. Parigi

109 G. J. van den Berg B. van der Klaauw

\section{Sorm}

K. Terrell

112 L. Bellmann T. Schank

113 R. Euwals
Labor Supply and Matching Rates for Welfare

Recipients: An Analysis Using Neighborhood Characteristics

Estimation in a Duration Model for Evaluating Educational Programs

Different Skill Levels and Firing Costs in a Matching Model with Uncertainty An Extension of Mortensen and Pissarides (1994)

Ownership or Performance: What Determines

Board of Directors' Turnover in Italy?

Job Tenure of Two Cohorts of Young German Men 1979 - 1990: An analysis of the (West-)German Employment Statistic Register Sample concerning multivariate failure times and unobserved heterogeneity

Fast Track or Failure: A Study of the Completion Rates of Graduate Students in Economics

Modeling Financial Incentives to Get Unemployed Back to Work

Combining Micro and Macro Unemployment

A Theory of Social Forces and Immigrant Second Language Acquisition

Sectoral Restructuring and Labor Mobility:

A Comparative Look at the Czech Republic

Innovations, Wages and Demand for

Heterogeneous Labour: New Evidence from a Matched Employer-Employee Data-Set

Do Mandatory Pensions Decrease Household 
114 G. Brunello

A. Medio

115 A. Cigno

F. C. Rosati

116 C. Belzil

117 S. Bender
A. Haas
C. Klose

118 M. A. Shields M. E. Ward

119 A. Lindbeck

D. J. Snower

120 P. T. Pereira P. S. Martins

J. C. van Ours

D. Munich

J. Svejnar

K. Terrell

123 J. Hunt

124 R. T. Riphahn

125 F. Büchel

J. R. Frick

126 J. Fersterer

R. Winter-Ebmer

127

M. Karanassou

D. J. Snower

128 O. Ashenfelter

D. Ashmore

O. Deschênes

129 B. R. Chiswick M. E. Hurst

130 G. Brunello

S. Comi

C. Lucifora
An Explanation of International Differences in

Education and Workplace Training

Why do Indian Children Work, and is it Bad for $\quad 7$ Them?

Unemployment Insurance and Subsequent Job

Duration: Job Matching vs. Unobserved

Heterogeneity

IAB Employment Subsample 1975-1995.

Opportunities for Analysis Provided by the

Anonymised Subsample

Improving Nurse Retention in the British National

Health Service: The Impact of Job Satisfaction on

Intentions to Quit

The Division of Labor and the Market for

Organizations

Does Education Reduce Wage Inequality?

Quantile Regressions Evidence from Fifteen

European Countries

Do Active Labor Market Policies Help Unemployed

Workers to Find and Keep Regular Jobs?

Returns to Human Capital under the Communist

Wage Grid and During the Transition to a Market

Economy

Why Do People Still Live in East Germany?

Rational Poverty or Poor Rationality? The Take-up of Social Assistance Benefits

The Income Portfolio of Immigrants in Germany -

Effects of Ethnic Origin and Assimilation. Or:

Who Gains from Income Re-Distribution?

Smoking, Discount Rates, and Returns to

Education

Characteristics of Unemployment Dynamics: The

Chain Reaction Approach

Do Unemployment Insurance Recipients Actively

Seek Work? Evidence From Randomized Trials in

Four U.S. States

The Employment, Unemployment and

Unemployment Compensation Benefits of

Immigrants

The Returns to Education in Italy: A New Look at the Evidence

$5 / 7 \quad 3 / 00$

Are Immigrants Favorably Self-Selected? An

Economic Analysis
5

$2 / 00$

$3 / 00$

$5 / 7 \quad 3 / 00$

$2 / 00$

$2 / 00$

$2 / 00$

$2 / 00$

$2 / 00$

$2 / 00$

$3 / 00$

$3 / 00$

$3 / 00$

$3 / 00$

$3 / 00$

$3 / 00$

$3 / 00$

$1 / 3 \quad 3 / 00$

1

$3 / 00$ 
Hours and Wages in the Engineering, 1926-1938

133 D. N. F. Bell

Paid and Unpaid Overtime Working in Germany and 1 the UK

R. A. Hart

O. Hübler

W. Schwerdt

134 A. D. Kugler

Hiring and Firing Costs, Adverse Selection and

$3 / 7$

$3 / 00$

G. Saint-Paul

Long-term Unemployment

135 A. Barrett

Is There a Wage Premium for Returning Irish

1

Migrants?

136 M. Bräuninger

Unemployment and Productivity Growth: An

Empirical Analysis within the Augmented Solow

Model

137 J.-St. Pischke

Continuous Training in Germany

7

$3 / 00$

138 J. Zweimüller

Firm-specific Training: Consequences for Job

1

Mobility

139 R. A. Hart

Y. Ma

Wages, Hours and Human Capital over the

Life Cycle

140 G. Brunello

S. Comi

Education and Earnings Growth: Evidence from $11 \quad$ 5/7

European Countries

141 R. Hujer

M. Wellner

The Effects of Public Sector Sponsored Training on

Individual Employment Performance in East

6

$4 / 00$

Germany 